\title{
Late Miocene fluvial distributary system in the northern Danube Basin (Pannonian Basin System): depositional processes, stratigraphic architecture and controlling factors of the Piešt’any Member (Volkovce Formation)
}

\author{
Michal ŠUJAN ${ }^{1, *}$, Michal KOVÁČ ${ }^{1}$, Jozef HÓK${ }^{1}$, Martin ŠUJAN², Régis BRAUCHER ${ }^{3}$, Samuel RYBÁR ${ }^{1}$ \\ and Arjan de LEEUW ${ }^{4}$ \\ 1 Comenius University in Bratislava, Department of Geology and Paleontology, Faculty of Natural Sciences, Ilkovičova 6 , \\ 84215 Bratislava, Slovakia \\ 2 EQUIS, Itd., Račianska 57, 83102 Bratislava, Slovakia \\ 3 Aix-Marseille Université, CEREGE, CNRS UM 34, F-13545 Aix-en-Provence, France \\ 4 CASP, West Building, 181A Huntingdon Road, Cambridge, CB3 ODH, United Kingdom
}

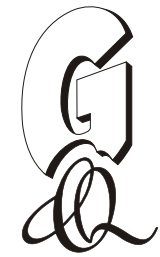

\begin{abstract}
Šujan, M., Kováč, M., Hók, J., Šujan, M., Braucher, R., Rybár, S., de Leeuw, A., 2017. Late Miocene fluvial distributary system in the northern Danube Basin (Pannonian Basin System): depositional processes, stratigraphic architecture and controlling factors of the Piešt'any Member (Volkovce Formation). Geological Quarterly, 61 (3): 521-548, doi: 10.7306/gq.1360

Aim of the study was to investigate the detailed stratigraphic architecture of the alluvial Volkovce Formation, which was deposited in the northern Danube Basin during the interval between 10 and $6 \mathrm{Ma}$. Two type locality exposures were subject to facies analysis and interpretation of depositional processes and $>500$ boreholes served for correlation of spatial variability in the character of the formation. The study was focused on the northern Blatné and western Rišñovce depressions, which are partly separated by the Považský Inovec Mountains horst. It was revealed, that a mostly gravelly fluvial distributary system of the Piešt'any Member was deposited in the northern Blatné depression, partly confined by the exposed horst and by incised palaeotopography. The sequence is composed of amalgamated braided river channel bodies with no overbank strata, in response to high sediment supply and low accommodation. The palaeo-stream then crossed the horst in its southern part towards the Rišňovce depression, where there was four times more accommodation. The submerged horst acted as a boundary, where the depositional processes changed to a meandering river and significant overbank deposits started to be preserved. Only small streams were present in the northern Rišňovce depression, which led to very low sediment supply compared to the high accommodation there. The depositional system was affected mainly by the incised palaeotopography, by the location of sediment input together with spatial differences in accommodation rate caused by the activity of the Ripňany Fault on the southeastern side of the Považský Inovec Mts.
\end{abstract}

Key words: fluvial distributary system, facies analysis, sediment supply, accommodation, Pannonian Basin System, late Miocene.

\section{INTRODUCTION}

Fluvial distributary systems (FDS) represent depositional environments that form in areas where a rapid change in a river transport capacity occurs. The distributary pattern results from continuous radial reallocation of channels and their branching which leads to decrease of channel depth and of water discharge (e.g., Nichols and Fisher, 2007). FDS typically consist of a range of sedimentary environments the character of which strongly depends on climate and tectonic setting. The morphology of FDS results from pre-existing topography and interplay

* Corresponding author, e-mail: miso@equis.sk

Received: August 6, 2016; accepted: March 14, 2017; first published online: May 16, 2017 between accommodation rate and sediment supply (e.g., MacCarthy, 1990; Blair and McPherson, 1994; Harvey et al., 2005; Hickson et al., 2005; Pope and Wilkinson, 2005; Nichols and Fisher, 2007; Blair and McPherson, 2009; Straub and Esposito, 2013; Straub and Wang, 2013). An analysis of evolution of such a depositional system needs a detailed approach with consideration of variable input data. In this study, we present an analysis of the depositional processes, spatial geometry and factors affecting the Tortonian-Messinian FDS in the northern part of the Pannonian Basin System (PBS).

Important advances were achieved recently in basin scale stratigraphy of the PBS regarding genetic definition of the late Miocene formations (e.g., Magyar et al., 2007, 2013; Kováč et al., 2011). The timing of the heterochronous progradation of depositional systems across the individual basins due to filling of deep basin depocenters is now well-constrained (e.g., Magyar et al., 2013; Sztanó et al., 2016; Šujan et al., 2016). However, detailed studies of the internal architecture of upper Miocene alluvial formations of the PBS are still rare. This is true es- 


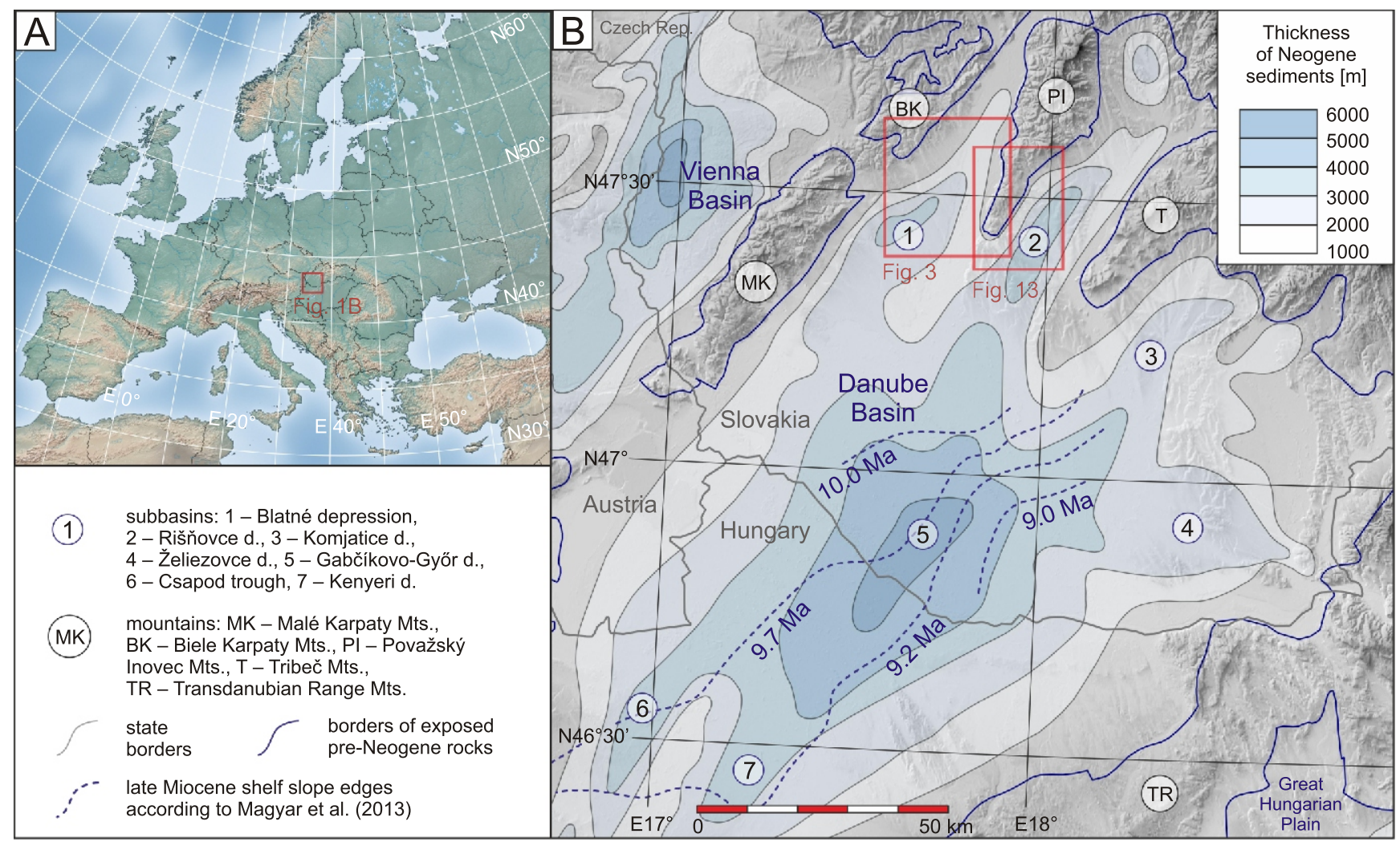

Fig. 1. Location of the study area

A - approximate location of the Danube Basin in Central Europe; B - location of the study areas within the Danube Basin; names of depressions according to Vass et al. (1988), Kováč et al. (2011) and Mattick et al. (1996); position of the Lake Pannon shelf edges according to Magyar et al. (2013)

pecially for the northern Danube Basin. The aim of this study was to identify the stratigraphic architecture of the upper Miocene alluvial Volkovce Formation and its component Pieštany Member (which represent an example of ancient FDS). More than 500 boreholes were analysed for this purpose together with facies analysis of two key outcrop localities.

Besides analysis of facies distribution, the controlling factors influencing deposition of the alluvial sequence were investigated by examining the spatial variability of the alluvial deposits and the morphology of stratigraphic surfaces. The research was focused on factors affecting the variability of accommodation rate and sediment supply, such as tectonic activity, initial topography and compaction of the whole basin fill. Depositional conditions were specific because of the presence of a mountain horst, which partly separated the two depressions studied. Integration of genetic criteria to the stratigraphy of the northern part of the Danube Basin allowed us to characterize the palaeo-river network during an interval of $4 \mathrm{My}$, between 10 and $6 \mathrm{Ma}$. The framework described comprises a first attempt of detailed stratigraphic architecture analysis of the upper Miocene alluvial sequence in the Danube Basin.

\section{GEOLOGICAL SETTING}

The Danube Basin, a sub-basin of the Pannonian Basin System, is located between the mountain ranges of the Eastern Alps, Western Carpathians and the Transdanubian Range (Fig. 1). Its northern part is represented by separate depressions/embayments between the mountain ranges of the Malé
Karpaty, Považský Inovec and Tribeč Mountains. These are from north-west to south-east: the Blatné, Rišňovce, Komjatice and Želiezovce depressions. The central part of the basin is called the Gabčíkovo-Györ depression (Vass et al., 1988; Kováč et al., 2011). The Csapod trough and Kenyeri depression are situated to the south-east of the central depocenter (Fig. 1B; Mattick et al., 1996).

The basin subsidence and accumulation history consists of three main stages: (1) an early Miocene piggy-back (wedge top) phase in which mostly marine deposits were preserved mainly in the northern embayments, (2) a middle Miocene phase with accumulation of high volumes of mostly marine and deltaic sequences deposited during the basin syn-rift subsidence, which was associated with voluminous volcanic activity, and (3) a late Miocene to Pliocene phase with prevailing brackish to freshwater sedimentation of Lake Pannon followed by terrestrial sedimentation in the phase of thermal subsidence (Kováč, 2000; Kováč et al., 2011).

The study area, represented by the northern Blatné depression and western part of the Rišňovce depression, is characterized by moderately low to hilly terrain. The Neogene basin is bordered by morphostructures comprising the pre-Cenozoic complexes of the Tatric, Fatric and Hronic superunits: the Malé Karpaty Mts. to the north-west, the Považský Inovec Mts. partly separating the two studied depressions and the Tribeč Mts. to the south-east (Fig. 1B). The same rock complexes of Paleozoic and Mesozoic age form the basement of the part of the Danube Basin studied. Locally, Paleogene strata underlie the Neogene sequences (Maglay et al., 2011). 


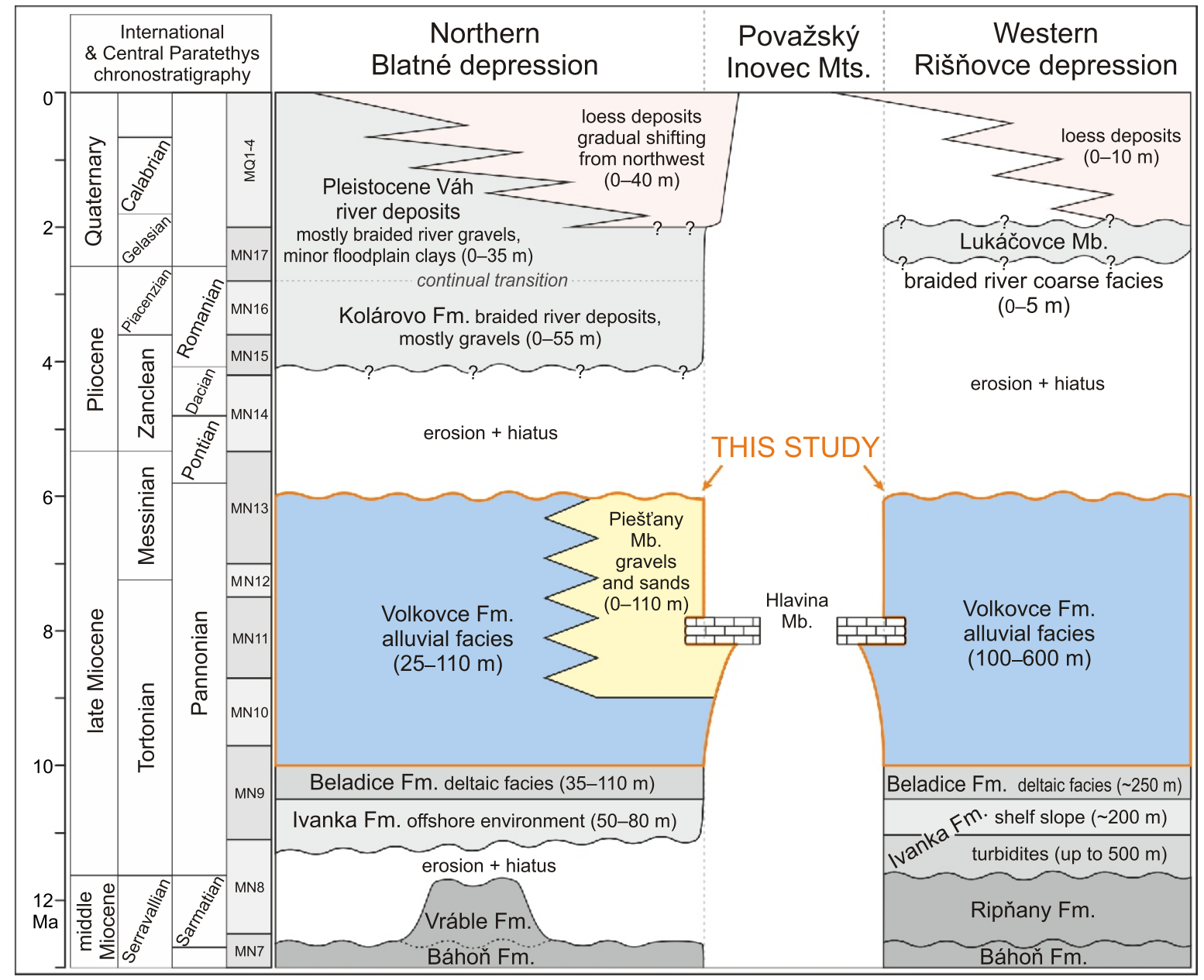

Fig. 2. Lithostratigraphy of the Neogene and Quaternary deposits in the Blatné and Rišňovce depressions

Lithostratigraphy is based on Kováč et al. (2011), Šujan et al. (2016) and Sztanó et al. (2016); standard Neogene stages sensu Cohen et al. (2013) and Central Paratethys stratigraphy sensu Kováč et al. (2011); MN and MQ - mammal biozone stages sensu Steininger (1999); numbers in brackets represent thicknesses typical for each lithostratigraphic unit

These northernmost depocenters of the Danube Basin were subject to the most significant subsidence during the middle Miocene with a sediment thickness of $>3000 \mathrm{~m}$ (Fig. 1B; Rybár et al., 2015, 2016). After intense rifting during the Langhian (lower Badenian), the rate of subsidence gradually decreased. The late Serravallian (Sarmatian) sequence reflects brackish regressive sedimentation, which continued to the beginning of the late Miocene (11.6 Ma; Kováč et al., 2011). After isolation of the Pannonian Basin System from the Mediterranean and Eastern Paratethys, Lake Pannon gradually flooded the surrounding areas until it reached its highest extent at $\sim 10.5-10.0 \mathrm{Ma}$ (e.g., Magyar et al., 1999; Harzhauser et al., 2008). Progradation of the shelf margin that was fed by deltaic systems of the palaeo-Danube and rivers draining the Western Carpathians led to a gradual retreat of the Lake Pannon shoreline to the south-east (Fig. 1B; Magyar et al., 2013). The main water body was characterized by brackish salinity for most of its existence (Uhrin, 2011). The filling of the northern Danube Basin started in the north-west $\sim 10.5 \mathrm{Ma}$ and prograded across the basin towards the south-east up to 2.7 Ma (Magyar et al., 2013; Sztanó et al., 2016; Šujan et al.,
2016). Predominantly terrestrial sedimentation prevailed in the whole northern Danube Basin after 8.9-8.7 Ma (Kováč et al., 2011; Šujan et al., 2016).

Concerning the upper Miocene stratigraphy of the northern Blatné depression, the Ivanka Fm. started to accumulate in a shallow brackish lacustrine environment probably from 11.6-11.4 Ma (Fig. 2; Kováč et al., 2006; Rybár et al., 2016). The shallow lacustrine deposition was followed by deposition of the deltaic Beladice Formation that includes prodelta, delta front and shoreface, delta plain and lagoonal facies. The Beladice Formation typically contains a mixture of brackish and freshwater molluscs and ostracods (Baráth et al., 1999; Rybár et al., 2016). Precise timing of the final Lake Pannon shoreline regression in the Blatné depression was proposed to be $\sim 10.0 \mathrm{Ma}$ (Sztanó et al., 2016; Šujan et al., 2016). Normal regression of Lake Pannon coincided with the start of deposition of the alluvial Volkovce Formation, which is the subject of this study. The Volkovce Formation is discordantly overlain by the Late Pliocene coarse-grained alluvial Kolárovo Fm. and Quaternary deposits of alluvial and aeolian origin (Fig. 2; Rybár et al., 2016). 
The Rišňovce depression was characterized by a higher rate of late Miocene subsidence and the forming of a deep basin depocenter, which was filled by a turbidite-shelf slopedeltaic depositional system in the time span 11.0-10.6 Ma (Fig. 2; Sztanó et al., 2016; Šujan et al., 2016). The alluvial environment of the Volkovce Fm. started to dominate after this period. In the area of the western Rišňovce depression, the Volkovce Formation is overlain by a relatively thin loess cover and locally by small remnants of terraces of the Early Pleistocene coarse-grained alluvial Lukáčovce Member (Fig. 2; Šarinová and Maglay, 2002).

The Považský Inovec Mountains separate the two depressions and formed a subaerially exposed swell during the deposition of the Volkovce Formation. This is documented by the position of the Pieštany Member above the pre-Cenozoic complexes, without the presence of older formations (Fig. 2). Therefore, the specific role of the Považský Inovec Mountains in the evolution of these sequences is investigated by this study.

The Piešt'any Member is considered in this study as a member of the alluvial Volkovce Formation (Fig. 2). This several tens of metres thick sandy-gravelly succession crops out in the vicinity of the town of Pieštany in the western foothills of the Považský Inovec Mountains. Small exposures rim the margin of the morphostructure towards the south (Fig. 3; Sliva et al., 2007). The exposures around Pieštany provided an excellent opportunity to determine depositional processes through facies analysis. Authigenic ${ }^{10} \mathrm{Be} /{ }^{9} \mathrm{Be}$ dating (five ages published in Šujan et al., 2016; location of samples in Fig. 3) provided an age of $\sim 9.0 \mathrm{Ma}$ for the start of the sandy-gravelly sedimentation of the Pieštany Member and constrained its upper age limit to $\sim 6.0 \mathrm{Ma}$ (Fig. 2). This upper age limit is supported by the occurrence of a skull of Deinotherium proavum (Musil, 1959); than reinterpreted by (Tóth, 2010). The skull came from $19 \mathrm{~m}$ below ground in a construction pit close to the well Bu-114 (Fig. 3), and is representative of the MN12 mammal biozone with age range 7.5 to $6.8 \mathrm{Ma}$ (Agustí et al., 2001). Dating of the Hlohovec-Pastuchov exposure, located on the southern margin of the Považský Inovec Mts. (Fig. 3), has constrained its depositional age to 6.5-6.0 Ma (two ages published in Šujan et al., 2016). This enabled its interpretation as a lateral equivalent of the younger part of the Pieštany Member and it was the second subject of a facies analysis.

The Hlavina Member, which is important for age determination of the succession studied, is according to Fordinál and Nagy (1997) formed of freshwater carbonates that accumulated along tectonic lines bounding the marginal mountains of the northern Danube Basin, such as the Považský Inovec Mountains. These deposits were dated to $\sim 8.0 \mathrm{Ma}$ using small mammal biostratigraphy and molluscs (Fordinál and Nagy, 1997; Kováč et al., 2010, 2011). Their accumulation is considered to have been a result of tectonic activity. Hlavina Member deposits crop out along both margins of the Považský Inovec Mountains and could be found together with the Pieštany Member near Ratnovce (Fig. 3). They consist of sandstone clasts of the Pieštany Member (Maglay et al., 2011), indicating that at least the lower part of the member had accumulated before $8.0 \mathrm{Ma}$. The Hlavina Member was considered by Kováč et al. (2011) as a marginal facies of the Volkovce Formation (Fig. 2).

The Volkovce Formation represents a succession of alluvial deposits distributed across the Danube Basin with time span of sedimentation ranging across $10.0-6.0 \mathrm{Ma}$. Its thickness in the Blatné depression reaches $50-200 \mathrm{~m}$ and in the Rišňovce depression it is $100-600 \mathrm{~m}$. The internal architecture of the forma- tion has not been previously described, representing a gap in the knowledge of the depositional, tectonic and climatic evolution of the basin. This study intends to provide this missing information.

\section{METHODS}

The study is based on a detailed analysis of borehole stratigraphic and geophysical logs (present in the archives of Slovak Geological Survey and of Nafta, a.s. company) and on facies analysis of two exposures, to determine the spatial variability of the internal stratigraphy of the alluvial Volkovce Formation in the northern Blatné depression and western Rišňovce depression of the Danube Basin.

Despite the poor exposure of the upper Miocene sequences, two representative outcrops situated along the Považský Inovec Mountains provided us with a window into the detailed lithofacies composition of the alluvial sequence studied. These represent (1) a coarse-grained proximal sequence of the type Pieštany Member and (2) a distal sandy to fine-grained Hlohovec-Pastuchov facies. A log of the Pieštany-Banka locality was composed from several exposures located close to each other. Several outcrops of the Volkovce Formation with comparable lithologies were documented in the western Rišňovce depression. The Hlohovec-Pastuchov locality was selected for detailed research as the most representative one. The lithofacies were defined, depositional processes were determined and finally facies associations were interpreted according to Miall (2000, 2006). Palaeocurrent directions were determined by field measurement of dip direction of planar or trough cross-stratified strata. 25 measurements for the Piešt'any-Banka locality and 27 measurements for the Hlohovec-Pastuchov locality were performed. Similarly, the direction of migration of lateral accretion at the Hlohovec-Pastuchov locality was determined by dip direction of accretion surfaces based on 13 measurements.

Surface exposures of of this succession in the Blatné depression are rare because of the gentle surface morphology and thick blanket of the Pliocene-Quaternary deposits. It is therefore possible to study their detailed composition and spatial lithological trends only using borehole data and geophysical records. For the purposes of this study, a number of boreholes were obtained from the Geofond archive of the Slovak Geological Survey. The main dataset is based on 372 counter-flush boreholes (CF), comprising the Bučany borehole series with depth of up to $600 \mathrm{~m}$ (129 boreholes) and the Pieštany and Špačince borehole series both with depths of up to $300 \mathrm{~m}$ (243 boreholes). These boreholes were drilled during the 1960's in a dense grid (distances 500-1000 m) for the purpose of hydrocarbon prospection (Fig. 3). The original lithological descriptions of the borehole profiles, which were used in this study, are provided in manuscript reports accessible in the Slovak Geological Survey (Hromec, 1961; Lunga, 1963, 1964a, b, 1965, 1966; Čermák, 1969). Depending on the drilling method, the profiles were inferred from continuous small diameter cores. The grid of these boreholes was supplemented by lithological profiles of 120 hydrogeological wells.

A well-log electrofacies study of the spontaneous potential and resistivity record from 41 deep structural boreholes from the northern Blatné depression provided a control for the lithostratigraphic architecture of the upper Miocene alluvial succession especially for trends of lithological changes between the sedimentary units. The electrofacies are interpreted accord- 


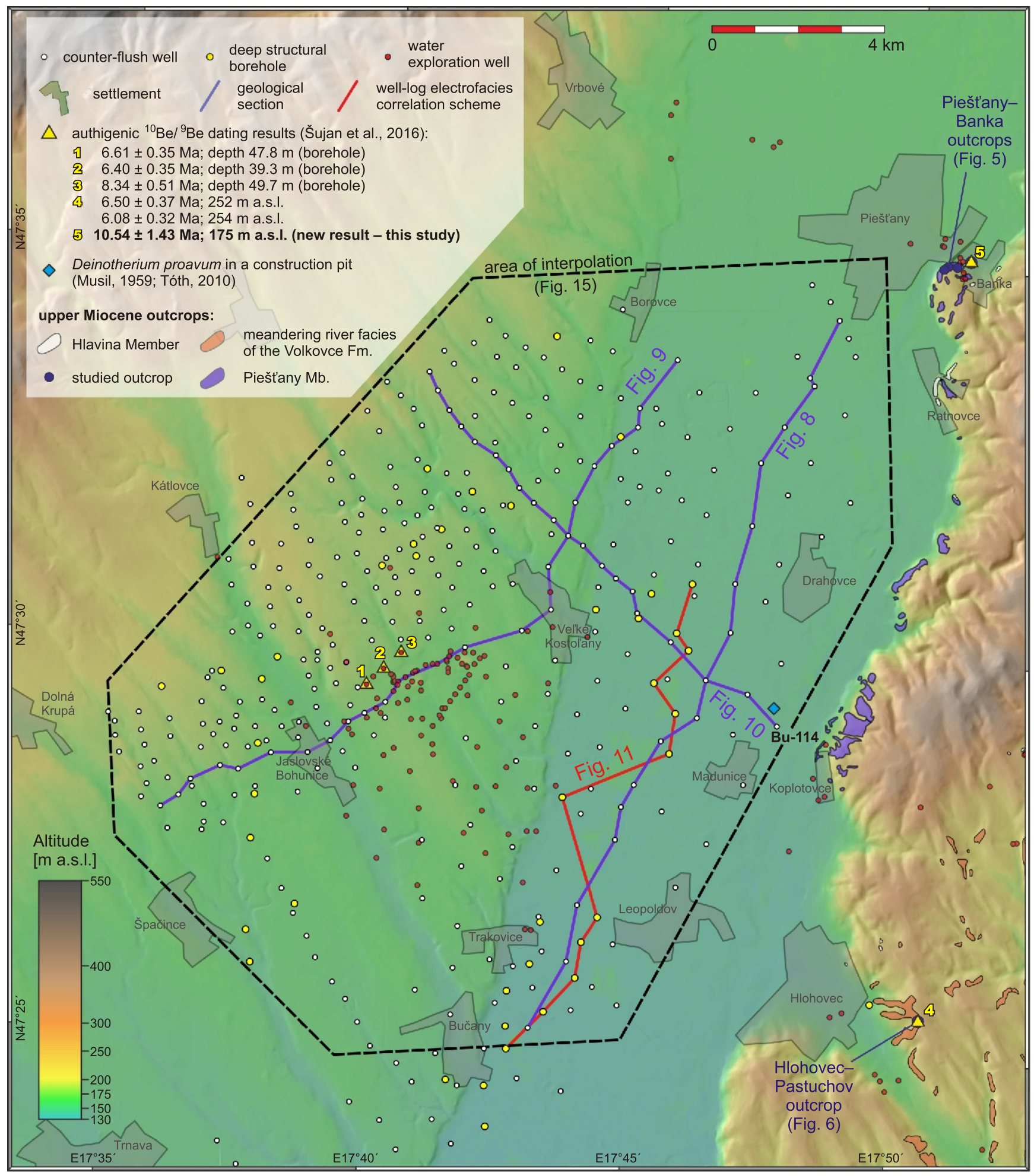

Fig. 3. Map of the area studied with analysed wells and type localities

Dating results were obtained by the authigenic ${ }^{10} \mathrm{Be} /{ }^{9} \mathrm{Be}$ dating method (Šujan et al., 2016; and this study); location of the upper Miocene outcrops according to Pristaš et al. (2000) and Maglay et al. (2006) 
ing to principles summarized by Catuneanu (2006), and according to existing applications of Juhász et al. (2004), Nádor and Sztanó (2011) and López and Steel (2015). The spatial distribution of all the boreholes acquired from the northern Blatné depression is shown in Figure 3.

The western Rišňovce depression was not drilled as extensively. 65 lithological profiles of water exploration wells were collected. The lithological profiles of all hydrogeological wells studied were originally based on cuttings or counter-flush (CF) cores, depending on the drilling method used. These wells were supported by six CF boreholes of the Vel'ké Zálužie series with depths of up to $600 \mathrm{~m}$, which penetrated the whole Volkovce Fm.

The lithologies of the borehole profiles were digitized using the following code: (1) clays and silts, (2) sandy clays and sandy silts/clayey or silty sands, (3) sands, (4) gravelly sands, (5) gravels and (6) coal layers and coaly clays. The lithotype of clays and silts was divided into two portions according to its origin sensu McCarthy et al. (1998) using the following features: (a) massive, often variegated, greenish to brownish, containing reddish ferric mottles, calcareous nodules and pedogenic horizons, with a terrestrial or no mollusc fauna, considered as terrestrial and floodplain, and (b) occasionally laminated, with grey to blue colours, containing a freshwater and terrestrial mollusc fauna, and lacking indications of subaerial weathering interpreted as pond, oxbow lake or lacustrine in origin. The characteristics of the facies studied are summarized in Figure 4. Apart from these facies there are Quaternary loess and loess loams, which could be clearly recognized in the logs. However, they were not the object of the study and were thus attributed to terrestrial clays and silts. The facies identified were interpreted according to their origin and grouped into facies associations based on Miall (2006), Amorosi et al. (2008) and Campo et al.

\begin{tabular}{|c|c|}
\hline $\begin{array}{l}\text { Lithotype Category } \\
\text { symbol }\end{array}$ & Features mentioned in original description \\
\hline \multirow{2}{*}{ gravel } & $\begin{array}{l}\text { variable grain size, mostly medium } \\
\text { and fine gravel, mainly quartzite and quartz, } \\
\text { occasionally granite, grey and yellow colours }\end{array}$ \\
\hline & $\begin{array}{l}\text { Kolárovo Fm. differences - occurrence of boulders, } \\
\text { variable petrography (quartz, sandstone, granite, } \\
\text { carbonates, chert), reddish and yellowish }\end{array}$ \\
\hline \multirow[t]{2}{*}{ gravelly sand } & $\begin{array}{l}\text { coarse to fine sand with occurrence of pebbles, } \\
\text { or less frequent clays and silts with considerable } \\
\text { amount of gravel admixture, in lower layers frequent } \\
\text { admixture of coal detritus }\end{array}$ \\
\hline & $\begin{array}{l}\text { lower Volkovce Fm. differences - reddish } \\
\text { sandy-clayey matrix }\end{array}$ \\
\hline & light grey to yelow, fine to coarse \\
\hline sand & $\begin{array}{l}\text { Kolárovo Fm. differences - varied, reddish } \\
\text { to brownish, often coarse and angular }\end{array}$ \\
\hline $\begin{array}{l}\text { sandy clay, } \\
\text { sandy silt }\end{array}$ & $\begin{array}{l}\text { clay or silt with considerable sandy admixture, } \\
\text { up to very clayey or silty sand, clay or silt with } \\
\text { frequent sandy laminae, varied and brownish, } \\
\text { with ferric mottles }\end{array}$ \\
\hline $\begin{array}{l}\text { floodpain clay } \\
\text { and silt }\end{array}$ & $\begin{array}{l}\text { varied, greenish to brownish, containing reddish ferric } \\
\text { mottles, calcareous nodules and pedogenic horizons, } \\
\text { minor fine to medium sand admixture common, } \\
\text { with terrestrial or no mollusc fauna }\end{array}$ \\
\hline $\begin{array}{l}\text { pond or lacustrine } \\
\text { clay and silt }\end{array}$ & $\begin{array}{l}\text { grey, green and blue, containing freshwater } \\
\text { or brackish mollusc fauna, calcareous and marly, } \\
\text { no subaerial weathering marks }\end{array}$ \\
\hline $\begin{array}{l}\text { coal, coaly clay, } \\
\text { plant redeposits }\end{array}$ & $\begin{array}{l}\text { coaly layer, lignite, coaly clay, } \\
\text { redeposited coal or plant detritus }\end{array}$ \\
\hline
\end{tabular}

Fig. 4. Lithotypes of the alluvial strata defined in this study for digitization of counter-flush well profiles Lithological characteristics, which were found distinctive for individual lithostratigraphic units during reinterpretation of this study, are mentioned when recognized
(2016). The genetic interpretation of the stratigraphic units is based mainly on depositional processes identified by facies analysis of correlative exposures.

Control factors on the spatial variation in the evolution of the alluvial sequence studied were investigated in the northern Blatné depression by construction of four surfaces: (1) pre-Cenozoic basement map, (2) base of the upper Miocene deposits, (3) base of the coarse-grained Pieštany Member and (4) base of the Pliocene-Quaternary deposits, which overlie the Pieštany Member discordantly. All four maps were constructed by the ordinary kriging method in the area of the polygon, which limits the distribution of the CF boreholes (Fig. 3). The surfaces of the upper Miocene base and pre-Cenozoic base were faulted in the interpolation, considering faults interpreted from seismic sections and well correlations by oil surveys (Vašek et al., 1961; Pavelka et al., 1963; Vejrostová and Adam, 1964; Pagáč, 1965; Lunga, 1968; Beinhauerová et al., 1969). Since the sequence studied appears in depths above the reach of the seismic surveys, they were not used in the detailed study. It was not possible to construct comparable structural maps in the western Rišňovce depression due to the low spatial density of borehole data and because only a few boreholes reached the base of the alluvial sequence. The lateral change of facies in the alluvial sequence was investigated in the northern Blatné depression using an interpolated map of percentage distribution of the coarse-grained lithotypes (gravels, sands with gravels, sands) in borehole profiles.

The resulting stratigraphic model of the Volkovce Formation allowed interpretations in terms of interplay between sediment supply and accommodation rate (e.g., Heller and Paola, 1996; Hickson et al., 2005; Nádor and Sztanó, 2011). This was performed according to sequence stratigraphic principles in intracontinental alluvial sequences (e.g., Martinsen et al., 1999; Püspöki et al., 2013).

The geochronology of the upper Miocene succession is inferred mostly from authigenic ${ }^{10} \mathrm{Be} /{ }^{9} \mathrm{Be}$ dating. This dating method was developed by Bourlès et al. (1989) and Lebatard et al. (2008), and a full description of the methodology used in the northern Danube Basin is given in Šujan et al. (2016). The location of the published dating results is indicated in Figure 3, together with one new unpublished result. Since the dating method is restricted to deposits containing clay particles, the new sample was taken from beneath the succession of the Pieštany-Banka outcrops, i.e. from the fine-grained part of the lower Volkovce Formation (Figs. 2, 3 and 5).

\section{RESULTS}

The resulting stratigraphic model consists of four separated parts. Lateral transition in facies associations of the Volkovce Formation at two representative localities situated along the foothills of the Považský Inovec Mountains is stated in the first part of the analysis. The second and third parts comprise borehole study of spatial changes in the alluvial sequence, which is analysed separately for the northern Blatné and western Rišňovce depressions. The fourth part is focused on the morphology of stratigraphic surfaces in the northern Blatné depression (cf. Fig. 1B).

The Volkovce Formation was deposited in the areas of the exposures studied, directly above the pre-Cenozoic complexes of the Považský Inovec Mountains (Fig. 2). Conversely, the basement of the sequence examined in both the depressions comprises the Beladice Fm., which could be distinguished in 


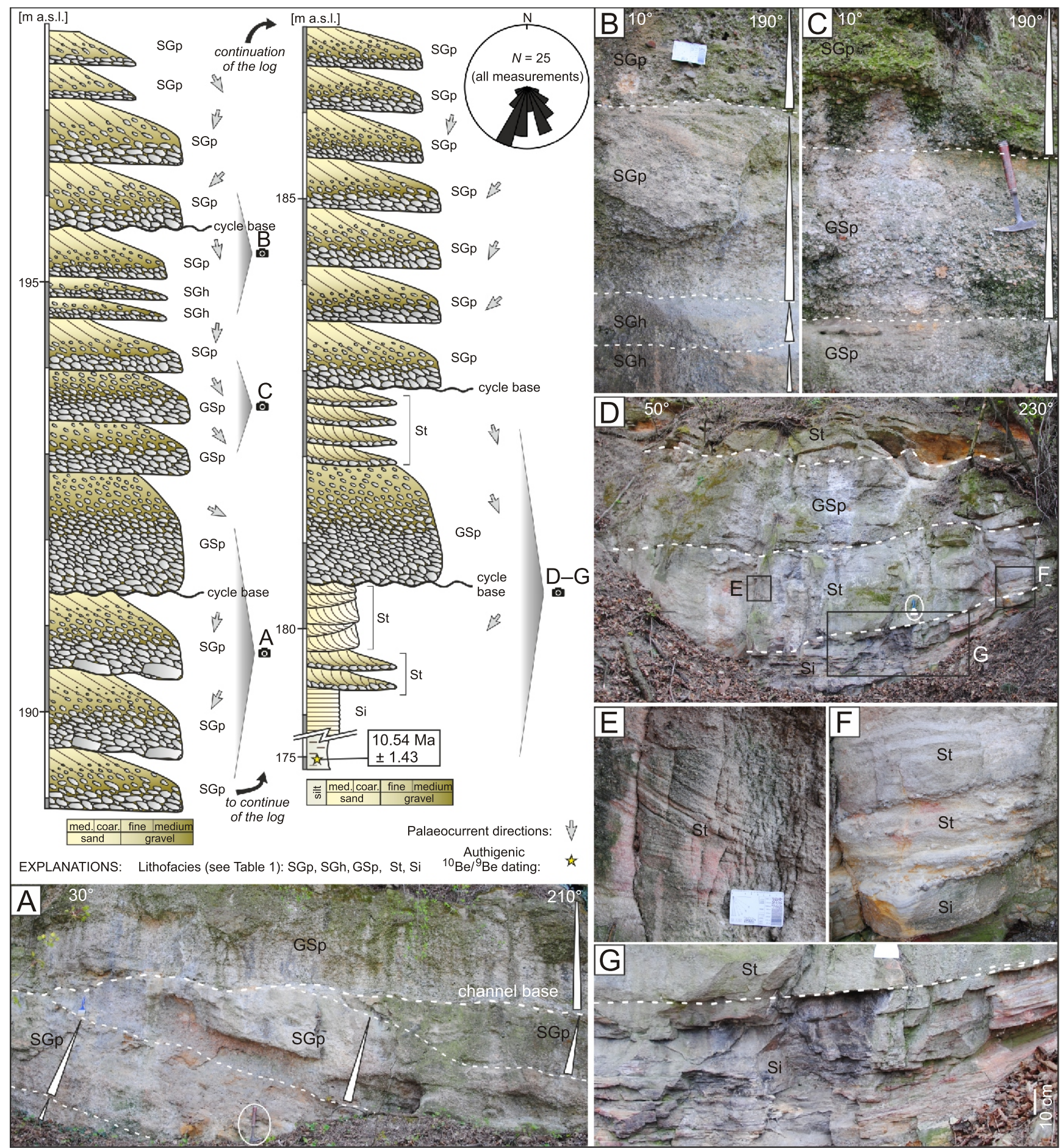

Fig. 5. Sedimentological logs of the Piešt'any-Banka locality with codes of lithofacies and labels of palaeoflow orientation

A - contact between inclined lenticular bars (SGp) in the lower portion of the outcrop with onset of a new channel cycle in the upper part (GSp), bounded by a sharp erosive base; B - transition from bars of lithofacies SGh to SGp with grain size gradation; C - bars GSp with grain size gradation; D - transition from medium to coarse sandy lithofacies to sandy-gravelly lithofacies; $\mathbf{E}$ - trough cross-stratified sands without gravel lag at the base; $\mathbf{F}$ - trough cross-stratified sands with a gravel lag at the base (St); $\mathbf{G}$ - medium-grained sand with low-angle inclined lamination (Si); lithofacies codes are explained in Table 1; the age $10.54 \pm 1.43 \mathrm{Ma}$ was obtained by the authigenic ${ }^{10} \mathrm{Be} /{ }^{9} \mathrm{Be}$ dating 
Summary of lithofacies description and interpretation from the Piešt'any-Banka and Hlohovec-Pastuchov localities (see Figs. 5 and 6)

\begin{tabular}{|c|c|c|c|c|c|}
\hline Facies association & $\begin{array}{l}\text { Litho- } \\
\text { facies } \\
\text { code }\end{array}$ & Lithofacies description & Lithofacies geometry & Depositional process & Sedimentary environment \\
\hline \multirow{3}{*}{$\begin{array}{l}\text { Amalgamated } \\
\text { channels of a braided } \\
\text { river in the proximal } \\
\text { zone of the fluvial } \\
\text { distributary system }\end{array}$} & SGp & $\begin{array}{c}\text { imbricated clast sup- } \\
\text { ported medium gravels, } \\
\text { passing upward into } \\
\text { planar cross-stratified } \\
\text { matrix supported me- } \\
\text { dium- to fine-grained } \\
\text { gravels, with coarse } \\
\text { sandy matrix, and } \\
\text { caped by uppermost } \\
\text { planar cross-stratified } \\
\text { coarse- to me- } \\
\text { dium-grained sand }\end{array}$ & $\begin{array}{c}\text { lenticular inclined } \\
\text { body with sharp pla- } \\
\text { nar scoured base and } \\
\text { top, with thickness } \\
50-80 \mathrm{~cm}\end{array}$ & $\begin{array}{c}\text { transition from gravelly } \\
\text { to sandy bedload } \\
\text { channelized traction } \\
\text { current }\end{array}$ & $\begin{array}{l}\text { downstream migrating } \\
\text { channel bar deposited in } \\
\text { main part of a braided } \\
\text { river channel }\end{array}$ \\
\hline & GSp & $\begin{array}{c}\text { imbricated clast sup- } \\
\text { ported medium gravels, } \\
\text { passing upward into } \\
\text { planar cross-stratified } \\
\text { matrix supported me- } \\
\text { dium- to fine-grained } \\
\text { gravels, with coarse } \\
\text { sandy matrix }\end{array}$ & $\begin{array}{l}\text { lenticular inclined } \\
\text { body with sharp } \\
\text { scoured strongly ero- } \\
\text { sive base and planar } \\
\text { scoured top, with } \\
\text { thickness } 50-150 \mathrm{~cm}\end{array}$ & $\begin{array}{c}\text { channelized traction } \\
\text { current with dominance } \\
\text { of gravelly bedload de- } \\
\text { posited by peak flow in } \\
\text { thalweg }\end{array}$ & $\begin{array}{c}\text { downstream migrating } \\
\text { channel bar deposited in } \\
\text { the deepest part of a river } \\
\text { channel }\end{array}$ \\
\hline & SGh & $\begin{array}{c}\text { horizontally arranged } \\
\text { clast supported fine } \\
\text { gravels, passing up- } \\
\text { ward into massive me- } \\
\text { dium- to } \\
\text { coarse-grained sand }\end{array}$ & $\begin{array}{l}\text { lenticular inclined } \\
\text { body with sharp pla- } \\
\text { nar base and top, } \\
\text { with thickness } \\
\sim 20 \mathrm{~cm}\end{array}$ & $\begin{array}{c}\text { transition from gravelly } \\
\text { to sandy bedload shal- } \\
\text { low channelized trac- } \\
\text { tion current }\end{array}$ & $\begin{array}{c}\text { downstream migrating } \\
\text { channel bar deposited in } \\
\text { shallow, almost filled } \\
\text { channel }\end{array}$ \\
\hline \multirow{2}{*}{$\begin{array}{l}\text { River channel } \\
\text { deposits without } \\
\text { specifying }\end{array}$} & St & $\begin{array}{l}\text { trough cross-stratified } \\
\text { medium to coarse } \\
\text { sand, locally with fine } \\
\text { gravel at the base }\end{array}$ & $\begin{array}{l}\text { lenticular body with } \\
\text { sharp concave up- } \\
\text { wards base and } \\
\text { sharp upper bound- } \\
\text { aries, 25-35 cm thick }\end{array}$ & $\begin{array}{c}\text { sandy bedload } \\
\text { channelized traction } \\
\text { current }\end{array}$ & $\begin{array}{l}\text { 3D dunes migrating in } \\
\text { shallow parts of a channel } \\
\text { and across the bars }\end{array}$ \\
\hline & Si & $\begin{array}{c}\text { medium-grained sand } \\
\text { with low angle inclined } \\
\text { lamination }\end{array}$ & $\begin{array}{l}\text { planar strata few cm } \\
\text { thick with fluent } \\
\text { boundaries }\end{array}$ & $\begin{array}{l}\text { shallow unchannelized } \\
\text { traction current }\end{array}$ & $\begin{array}{l}\text { overbank deposition proxi- } \\
\text { mal to a channel }\end{array}$ \\
\hline \multirow{5}{*}{$\begin{array}{l}\text { Meandering river } \\
\text { channel belt } \\
\text { in the distal zone of } \\
\text { the fluvial distributary } \\
\text { system }\end{array}$} & St & $\begin{array}{l}\text { trough cross-stratified } \\
\text { coarse sand, occasion- } \\
\text { ally with muddy } \\
\text { intraclasts }\end{array}$ & $\begin{array}{l}\text { lenticular body with } \\
\text { sharp concave base } \\
\text { and sharp upper } \\
\text { boundaries }\end{array}$ & $\begin{array}{c}\text { sandy bedload } \\
\text { channelized traction } \\
\text { current }\end{array}$ & $\begin{array}{c}\text { 3D dunes deposited in } \\
\text { thalweg of a laterally mi- } \\
\text { grating channel - sandy } \\
\text { bed macroform }\end{array}$ \\
\hline & Sr, SFf & $\begin{array}{l}\text { ripple cross-stratified } \\
\text { medium- to } \\
\text { fine-grained sand, with } \\
\text { varying proportion of } \\
\text { mud drapes of flaser } \\
\text { bedding }\end{array}$ & $\begin{array}{c}\text { continuous planar ho- } \\
\text { rizon with slightly } \\
\text { sharp transition from } \\
\text { underlying St and flu- } \\
\text { ent transition to over- } \\
\text { lying co-set of Fi and } \\
\text { Si }\end{array}$ & $\begin{array}{c}\text { traction current with } \\
\text { transition from sandy } \\
\text { bedload to suspended } \\
\text { load }\end{array}$ & $\begin{array}{c}\text { lower part of the inclined } \\
\text { heterolithic stratification } \\
\text { on transition from thalweg } \\
\text { deposition of migrating rip- } \\
\text { ples to lateral accretion of } \\
\text { a point bar in a river } \\
\text { channel }\end{array}$ \\
\hline & $\mathrm{Fi}$ & $\begin{array}{l}\text { silt to fine-grained silty } \\
\text { sand with low angle in- } \\
\text { clined lamination }\end{array}$ & $\begin{array}{l}\text { inclined planar strata } \\
\text { with sharp scoured } \\
\text { erosive upper and } \\
\text { lower boundaries, al- } \\
\text { ternated with Si }\end{array}$ & $\begin{array}{l}\text { suspended load trac- } \\
\text { tion current }\end{array}$ & \multirow{2}{*}{$\begin{array}{l}\text { inclined heterolithic strati- } \\
\text { fication (IHS) representing } \\
\text { laterally migrating point } \\
\text { bar in a river channel with } \\
\text { cyclic variation of high dis- } \\
\text { charge in a perennial river }\end{array}$} \\
\hline & $\mathrm{Si}, \mathrm{Sr}$ & $\begin{array}{l}\text { fine- to me- } \\
\text { dium-grained sand with } \\
\text { low angle inclined lami- } \\
\text { nation, locally with } \\
\text { small ripples and mud } \\
\text { drapes }\end{array}$ & $\begin{array}{l}\text { inclined planar strata } \\
\text { with sharp scoured } \\
\text { erosive upper and } \\
\text { lower boundaries, al- } \\
\text { ternated with Fi }\end{array}$ & $\begin{array}{c}\text { sandy bedload traction } \\
\text { current }\end{array}$ & \\
\hline & $\mathrm{Fm}, \mathrm{Fh}$ & $\begin{array}{c}\text { massive or very weakly } \\
\text { stratified clays and } \\
\text { silts, with reddish mot- } \\
\text { tles, calcretes, calcare- } \\
\text { ous incrustations and } \\
\text { rootlets }\end{array}$ & $\begin{array}{l}\text { horizon continuous in } \\
\text { lateral dimension }\end{array}$ & $\begin{array}{l}\text { deposition mainly from } \\
\text { suspension, then af- } \\
\text { fected by pedogenesis } \\
\text { with appearance of } \\
\text { vegetation }\end{array}$ & $\begin{array}{l}\text { overbank deposition in } \\
\text { floodplain environment }\end{array}$ \\
\hline
\end{tabular}


the boreholes from the overlying alluvial sequence by the presence of mixed brackish and freshwater molluscs and ostracods a high content of blue and green clays without weathering traces (subaquatic facies) and a much higher content of sandy and gravelly facies comparing with the overlying lower part of the Volkovce Formation (Rybár et al., 2016). The Volkovce Formation is overlain in the Blatné depression by the $20-40 \mathrm{~m}$ thick Pliocene-Quaternary Kolárovo Formation, which is composed mostly of fluvial gravels and gravelly sands (Fig. 2). This locally leads to problems in distinguishing from the underlying Pieštany Member in the northernmost part of the depression, but the boundary could be mostly correlated between boreholes using differences in petrography and colour (Fig. 4). The cover of the Volkovce Formation comprises, in the Rišňovce depression, only a thin Quaternary fluvial and aeolian succession.

\section{FACIES ANALYSIS OF THE VOLKOVCE FORMATION OUTCROPS ALONG THE POVAŽSKÝ INOVEC MOUNTAINS}

The proximal facies at the Piešt'any-Banka locality (Piešt'any Member). The Piešt'any Member appears on the surface in several 3-5 $\mathrm{m}$ high exposures in the foothills of the Považský Inovec Mountains between Pieštany and Banka (Fig. 3). A composite lithofacies log almost $20 \mathrm{~m}$ long was constructed from these outcrops. It represents a typical record of the proximal FDS (Fig. 5). The strata are strongly lithified by secondary cementation, probably associated with springs feeders of the freshwater carbonate sedimentation of the Hlavina Member (cf. Fig. 2).

The lowermost part of the exposures studied were sampled for authigenic ${ }^{10} \mathrm{Be} /{ }^{9} \mathrm{Be}$ dating. The new sample was taken from clays below the coarse sandy-gravelly succession of the Pieštany Member (Fig. 5), which correlates with the lower part of the Volkovce Formation described in the Blatné depression infill. The sample has an age of $10.54 \pm 1.43 \mathrm{Ma}$, in agreement within uncertainty with the expected time span of the lower part of the formation ranging 10.0-9.0 Ma (cf. Fig. 2).

D e s c ription. - The exposures consist of 2.5 to $4 \mathrm{~m}$ thick cycles, bounded by significantly erosive, horizontally oriented surfaces with obvious scours and an angular contact with underlying units (Fig. 5A). All observed lithofacies are summarized in Table 1. Most of the exposures are built of three types of gravely to sandy upward fining lithofacies:

1. Imbricated clast-supported medium gravels, passing upwards into planar cross-stratified matrix-supported medium to fine-grained gravels and terminating with planar cross-stratified coarse to medium-grained sand (lithofacies SGp; Fig. 5B). A gradual upward fining inside each unit is obvious. The thickness of the units is between 50 and $80 \mathrm{~cm}$ and they commonly reduce in thickness upwards within a cycle. The basal surface is rarely erosive. The thickest units contain angular sandstone intraclasts near their base (position in log $189.5 \mathrm{~m}$ and $190.5 \mathrm{~m}$ a.s.I.). The units dip parallel with the palaeoflow direction and have an inclination of $\sim 15^{\circ}$ (Fig. 5A). Unfortunately, the quality of outcrop allows an observation of their lenticular nature only locally.

2. Imbricated clast-supported medium gravels, passing upwards into planar cross-stratified matrix-supported medium to fine gravels, with no sandy termination (lithofacies GSp; Fig. 5C). An upward fining of the lithology in a single unit is also obvious. These units are usually situated in the lower part of the cycles just above the bounding erosive surface and may reach a thickness of $1.5 \mathrm{~m}$. This second type of upward fining lithofacies GSp usually passes up into first type of upward fining lithofacies SGp. The erosive base of unit is more common than in the first type. The inclination and lenticular nature of the units is similar to that of lithofacies SGp.

3. Horizontally arranged clast-supported fine gravel, passing into massive sandstone (lithofacies SGh; Fig. 5B). This type of upward fining lithofacies is thin $(\sim 20 \mathrm{~cm})$ and occurs less frequently in comparison with the previous two types. The gradation is more abrupt and its lower boundary is not erosive.

Gravels are rounded to well-rounded in all the described lithofacies, with the exception of sandstone intraclasts in the lithofacies SGp. The petrological composition is characteristic, with a predominance of quartz and a minor proportion of carbonates and cherts. Quartzite and granite occur locally (Maglay et al., 2011).

Trough cross-stratified coarse- to medium-grained sandstone, locally with fine-grained gravel at its base, forms most of the lower sandy part of the outcrop log (St; Fig. 5D-F). Trough cross-stratification reaches a thickness of $25-35 \mathrm{~cm}$ and is typical with a concave upwards erosive base. Medium-grained sandstone with low-angle inclined lamination was observed below the trough cross-stratified sands. Lithofacies Si forms a set of layers at least $60 \mathrm{~cm}$ thick with an inclination of $<15^{\circ}$ (Fig. 5G).

I n t e r p r e t a t i o n. - The gravelly-sandy upward fining lithofacies represents bar units formed by a channelized traction current, which is indicated by the thickness of the individual fining-upwards units (Table 1). SGp was deposited during the change from gravel bedload transport to sandy bedload, while the GSp was formed by gravel bedload passing into gravelly-sandy bedload transport. The gravel bedload transport prevails in the deeper part of a channel fill cycle with thalweg deposition. Thin units of SGh were probably deposited by traction current in the shallowest part of a channel, where 3D sandy dunes of trough-cross stratification (St) also formed (e.g., Bridge and Lunt, 2006; Kostic and Aigner, 2007).

The thickness of bar units and gravel content reflects variance of flow strength and depth in different parts of a channel. The orientation of the palaeoflow direction is of low variability, predominantly to the south (Fig. 5). This is indicative of a downstream accretion macroform according to Miall (2006). Palaeoflow depth should be comparable with the thickness of a single channel-fill cycle bounded by erosive surfaces with angular terminations of bar units (Bridge and Tye, 2000). Since the cross-stratified units SGp and GSp are not considered as dunes, thickness of individual units could not be used for flow depth calculation. These units are of inclined lenticular shape, forming integrated upward fining cycles bounded by erosive boundaries, which are considered as single channel fill bodies. Strongly erosive contacts indicate that the upper parts of the channel fills are probably missing. The thickness of single upward fining cycles reaches $4 \mathrm{~m}$ and palaeoflow depth may therefore be estimated to have been at least $4 \mathrm{~m}$.

The stacked pattern of the channel-fill facies and high degree of erosion, together with the occurrence of downstream accretion units and no preservation of overbank strata, suggests deposition by a braided river. The amalgamation of river channel bodies may indicate a low accommodation rate compared to sediment supply (e.g., McLaurin and Steel, 2007; López and Steel, 2015).

The lower part of the succession contains a considerably higher sand proportion, which might have been deposited in a minor channel of a braided stream. The low-angle inclined and 
laminated sands $(\mathrm{Si})$ may represent a levee or a point-bar facies, characteristic of a meandering river. However, there is not enough information for the proper interpretation of the lithofacies Si (cf. Fig. 5D, F, G).

Several interpretations of the lithostratigraphic position of the Piešt'any Member have been previously made. Most recently, Sliva et al. (2007) considered this member as a basal transgressive deposit of the lacustrine Ivanka Formation. Several authors described freshwater and terrestrial molluscs, but no brackish species was identified in situ from the Pieštany Member (Horusitzky, 1911; Čtyroký, 1959; Brestenská et al., 1961). Basal transgressive facies are very rare in the Ivanka Formation (Rybár et al., 2016), and in Lake Pannon usually reach only several metres of thickness (Csillag et al., 2010). Considering these facts and the fluvial origin of the exposures examined, the Pieštany Member is clearly a part of the Volkovce Formation (cf. Fig. 2).

The distal facies at the Hlohovec-Pastuchov locality. The succession observed at the Hlohovec-Pastuchov outcrop represents the youngest part of the Volkovce Formation, deposited at $\sim 6.5-6.0 \mathrm{Ma}$ according to authigenic ${ }^{10} \mathrm{Be} /{ }^{9} \mathrm{Be}$ dating (Šujan et al., 2016; dating results are shown in Figs. 3 and 6). The facies is similar to that seen in several other sandpits, which appear in the vicinity of the southern margin of the Považský Inovec Mountains. The face of the exposure is up to $7 \mathrm{~m}$ high and $150 \mathrm{~m}$ wide. The main part of the outcrop is depicted in Figure 6 and the lithofacies described are summarized in Table 1.

D e s c r i p t i o n. - The exposure shows three major alluvial units with different associations of lithofacies:

1. A unit of coarse sandy trough cross-stratified sets, situated in the lower part of the succession. The trough cross-stratified lenticular strata with concave-upwards bases (St) are 25-60 cm thick, with a mean value of $40 \mathrm{~cm}$ (Fig. 6A, G). Mud intraclasts lining the cross-stratification are common in the upper part of the trough cross-stratified unit (Fig. 6B). The base of the unit is not exposed and therefore its thickness could not be determined. The orientation of the trough cross-stratification varies along the exposure face from SSW to W (Fig. 6).

2. A unit of inclined heterolithic stratification (IHS) is situated in the middle part of the succession. The unit begins with a ripple cross-stratified unit of medium to fine sand $\sim 50 \mathrm{~cm}$ thick, with a varying proportion of mud drapes forming flaser bedding (SFf; Fig. 6B, C, E1). The contact with the underlying trough cross-stratified horizon is apparently not erosive.

The proportion of silt increases upwards. There are separate silty to fine-grained sandy layers that alternate with fine- to medium-grained sandy layers (Fig. 6D, E). This combination is designated as inclined heterolithic stratification (IHS) according to Thomas et al. (1987). The silts to fine-grained sands are laminated with low-angle inclination ( $\mathrm{Fi})$, while the fine- to medium-grained sandy layers are laminated with low-angle inclination (Si) to rip- ple cross-stratified ( $\mathrm{Sr}$ ) or flaser bedded sands with an admixture of fines (SFf). The thickness of the fine to medium sandy layers decreases upwards (from 40 to $20 \mathrm{~cm}$ ) and the silty to fine sandy layers thicken upwards (from 10 to $35 \mathrm{~cm}$ ), leading to an overall fining-upwards trend (see logs in Fig. 6). Contacts between individual layers are erosive and small scours may be observed (Fig. 6D, E). The lamination in the overlying layers usually follows the morphology of the erosive surface situated below. There are well-developed fossil roots in the lower part of IHS (Fig. 6F). These roots were developed on a silty to fine sandy surface and penetrate into the underlying medium sandy deposits. The palaeosurface on which they formed is highlighted by calcification features of an initial pedogenic horizon. The thickness of IHS varies from 2.0 to $3.0 \mathrm{~m}$ with an inclination of $\sim 25^{\circ}$ towards the $\mathrm{E}$ to SSE along the exposure face. Concave curved heterolithic layers are present in the upper part of IHS in the left part of the outcrop, forming a depression $\sim 6 \mathrm{~m}$ wide (Fig. 6).

3. A unit of massive or very weakly stratified clays and silts at the top of the succession consists of variegated massive clays with reddish mottles, calcretes, calcareous incrustations and rootlets (Fig. 6H). The horizon has a uniform thickness of $\sim 1.5 \mathrm{~m}$. The succession is overlain by a loess sequence of variable thickness (Fig. 6).

The petrography of the deposits was studied at a nearby outcrop. The composition of the sands examined consist predominantly of quartz with variable amounts of altered feldspars and rare muscovite. Heavy minerals include almandine, zircon and tourmaline (Šarinová and Slemenský, 2009).

Interpretation. - The lower unit may be considered as a set of 3D dunes, forming a thalweg deposit that accumulated from traction currents - a sandy bed macroform (SB; Miall, 2006). The IHS horizon is interpreted as a laterally accreted point bar in a meandering stream as described by Thomas et al. (1987). This is supported by the dip orientation of the lamination, in which that of IHS is perpendicular to that of the dunes that are situated below. The variation in lithology (finer and coarser fraction) indicates cyclicity in the river flow regime, with alternating sedimentation from traction currents and from suspension. Some erosive surfaces regularly bound finer as well as coarser layers. Their presence shows an increase in stream dynamics before the deposition of each layer. By contrast, the occurrence of fossil roots in the lower part of IHS reflects very low discharge and dynamics of the stream. There frequently is a gradual increase in the volume of the silty fraction through flaser bedding between the layers, indicating a gradual decrease in the flow's transport capacity. An upwards increase in the thickness of the fine-grained layers within IHS is common due to shallowing in the upper parts of the point bar resulting in a lower transport capacity there. A convex pattern in IHS in the upper left part of the outcrop (Fig. 6) is interpreted as a chute channel formed in the upper part of the point bar, similar to the one described by Ghazi and Mountney (2009). The uppermost massive to weakly stratified clays and silts were deposited from

Fig. 6. Lithology of the Hlohovec-Pastuchov exposure with extent of macroforms, sedimentological logs, codes of lithofacies and palaeoflow orientation

A - trough cross-stratified sands; $\mathbf{B}$ - transition from trough cross-stratified sands to ripple cross-stratified sands and to flaser bedding, note muddy intraclast a few $\mathrm{cm}$ in diameter marked in lithofacies St; C - ripple cross-stratified sands; D - detail of inclined heterolithic stratification (IHS), note the changing lithology and erosive contacts; $\mathbf{E}$ - detail of IHS with occurrence of ripples and flaser bedding, for more details see Figure E1; F - lower part of IHS consisting of fossil roots, which are formed in a silty layer together with an initial pedogenic horizon; G trough cross-stratified sands; $\mathbf{H}$ - floodplain fines overlain by a Quaternary loess sequence; lithofacies codes are explained in Table 1; dating results are according to Šujan et al. (2016) 


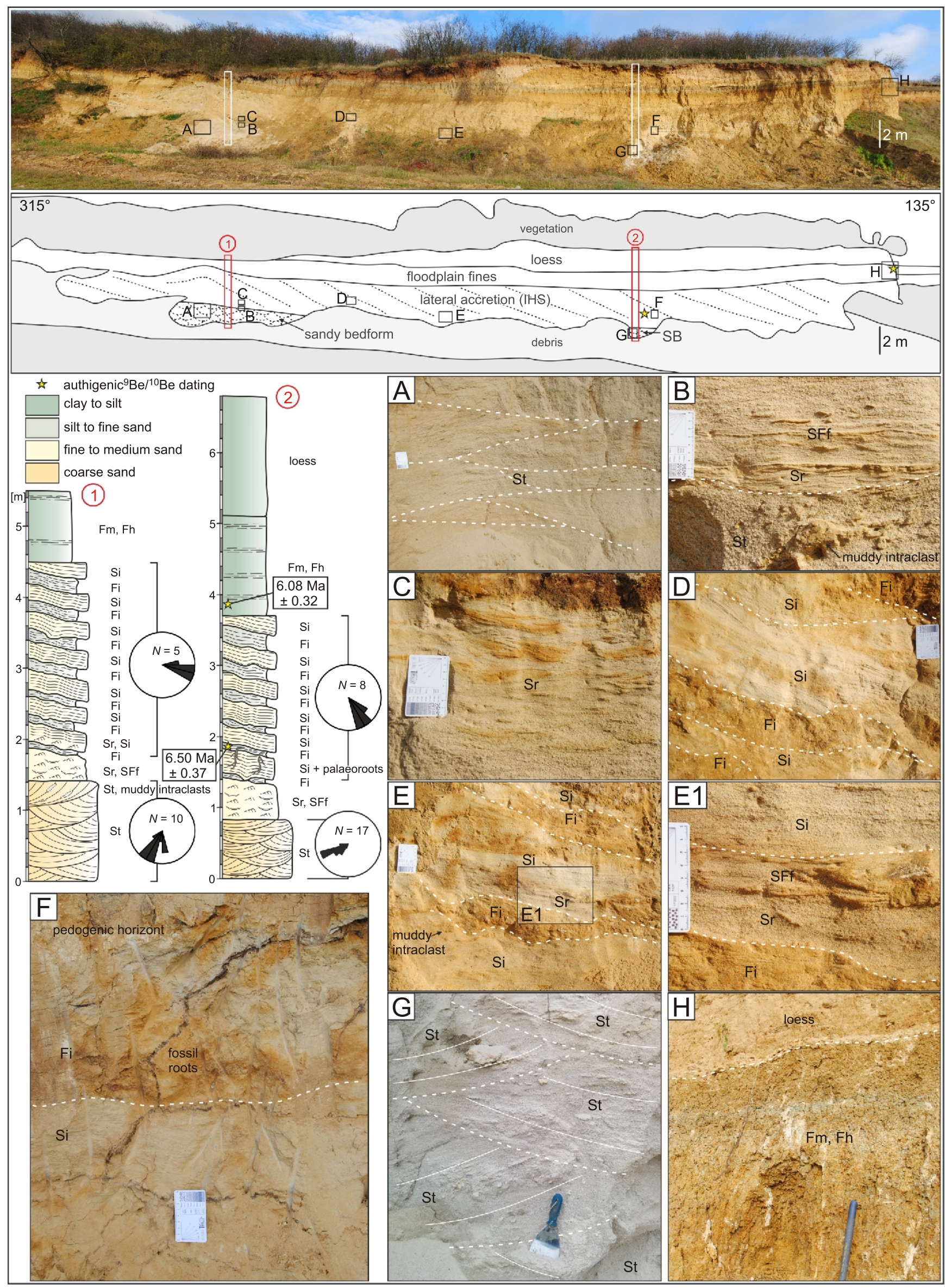


suspension in an unchannelized overbank environment, then modified by pedogenic and oxidation processes that are, inter alia, indicative of a floodplain origin (McCarthy et al., 1998; Campo et al., 2016).

The complete alluvial succession at the outcrop, together with the overlying overbank fines, constitutes an upwards fining cycle, typical of a meandering channel belt. The thickness of the laterally accreted point bar indicates a flow depth of at least $3 \mathrm{~m}$ (Bridge and Tye, 2000). Taking into account several published approaches of palaeoflow depth calculation based on mean thickness of the trough cross-stratified sets, the estimate ranges from $3.5 \mathrm{~m}$ (Allen, 1968; Bridge and Tye, 2000) to $5 \mathrm{~m}$, when considering erosion of a dune before deposition of a new cross-set (Leclair and Bridge, 2001). However, the degree of preservation of a dune during forming of a cross-set is hard to estimate. The general palaeoflow direction was towards the SW and migration of the channel was towards the SE.

\section{STRATIGRAPHIC ARCHITECTURE OF THE VOLKOVCE FORMATION IN THE NORTHERN BLATNÉ DEPRESSION INFERRED FROM BOREHOLES}

The characteristic facies and well log patterns of the alluvial sequence studied are depicted in Figure 7. The Volkovce For- mation consists of two distinct superposed units in the northern Blatné depression. The lower Volkovce Formation with a ratio between sandy-gravelly deposits and clays/silts ranging usually from 0.1 to 0.25 across the depression, consists only of the fine-grained alluvial succession (Fig. 7C). The upper Volkovce Formation, spatially heterogeneous with three laterally transitional zones, may be observed on geological sections and on maps of facies distribution that are included below. The documented transition forms a dominantly gravelly succession on the north (considered as an equivalent of the Pieštany Member; Fig. 7A), through a transitional succession (Fig. 7B), to the prevailingly clayey succession with low frequency of sandy bodies to the south (Fig. 7C). The bounding surface between these two units is an easily correlatable stratigraphical boundary in the northern Blatné depression.

\section{LOWER VOLKOVCE FORMATION}

D e s c r i p t i o n. - The lower unit of the Volkovce Formation is generally of very fine-grained composition, but locally contains up to $50 \%$ of gravelly layers and is spatially heterogeneous. It mainly consists of light brown and variegated clays with calcareous nodules, pedogenic features and reddish mottles, while laminated clays of grey, green to blue colours are less frequent, forming only several metre-thick intervals. Clays contain commonly freshwater (e.g., Brotia escheri, Bythinia sp.,

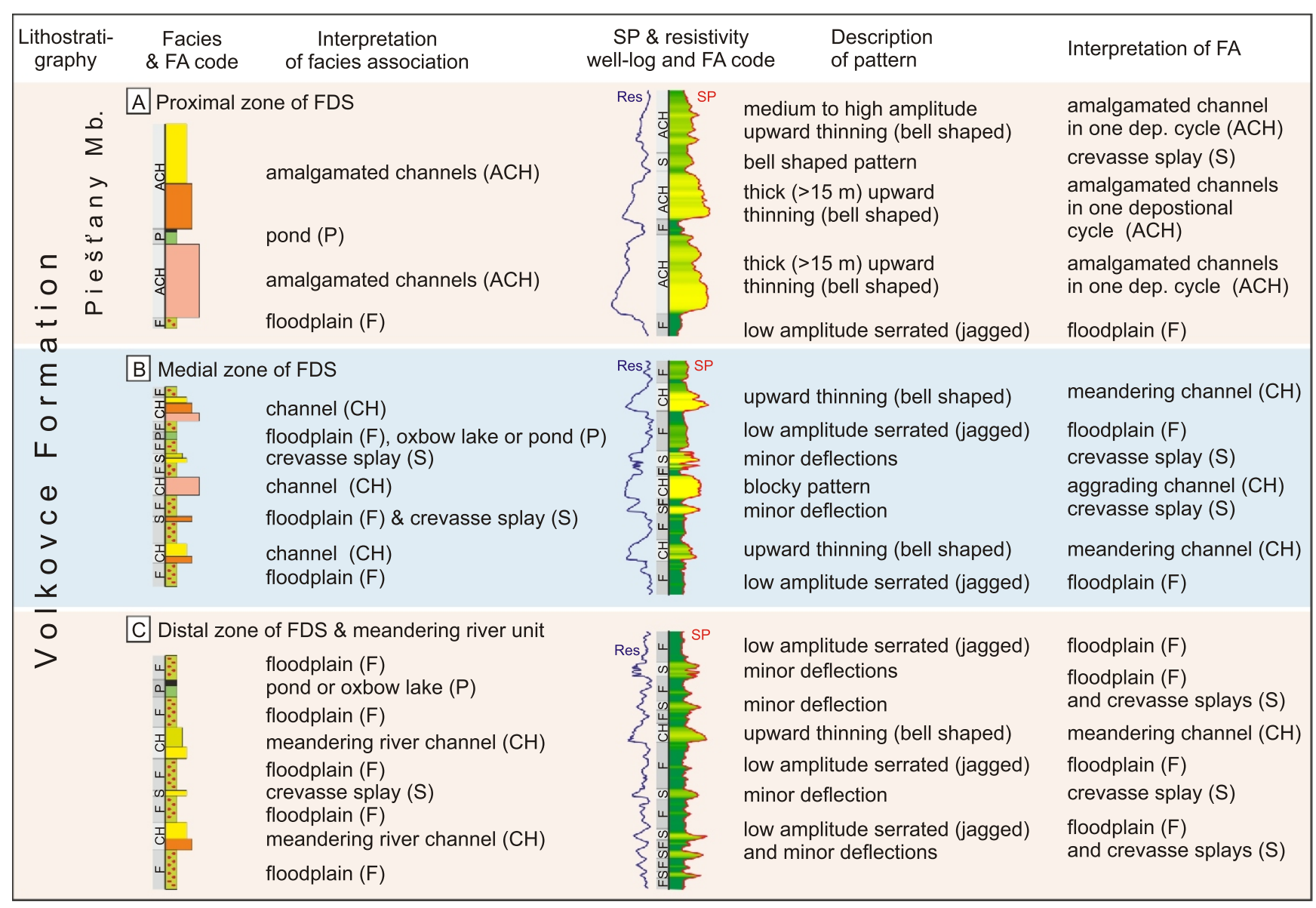

Fig. 7. Definition of zones of the fluvial distributary system in the Volkovce Formation

Definition is based on their characteristic facies associations inferred from distribution of lithotypes in well profiles, together with well log responses and their interpretation typical for each facies association; FDS - fluvial distributary system; FA - facies association; SP - spontaneous potential well-log; Res - resistivity well-log 


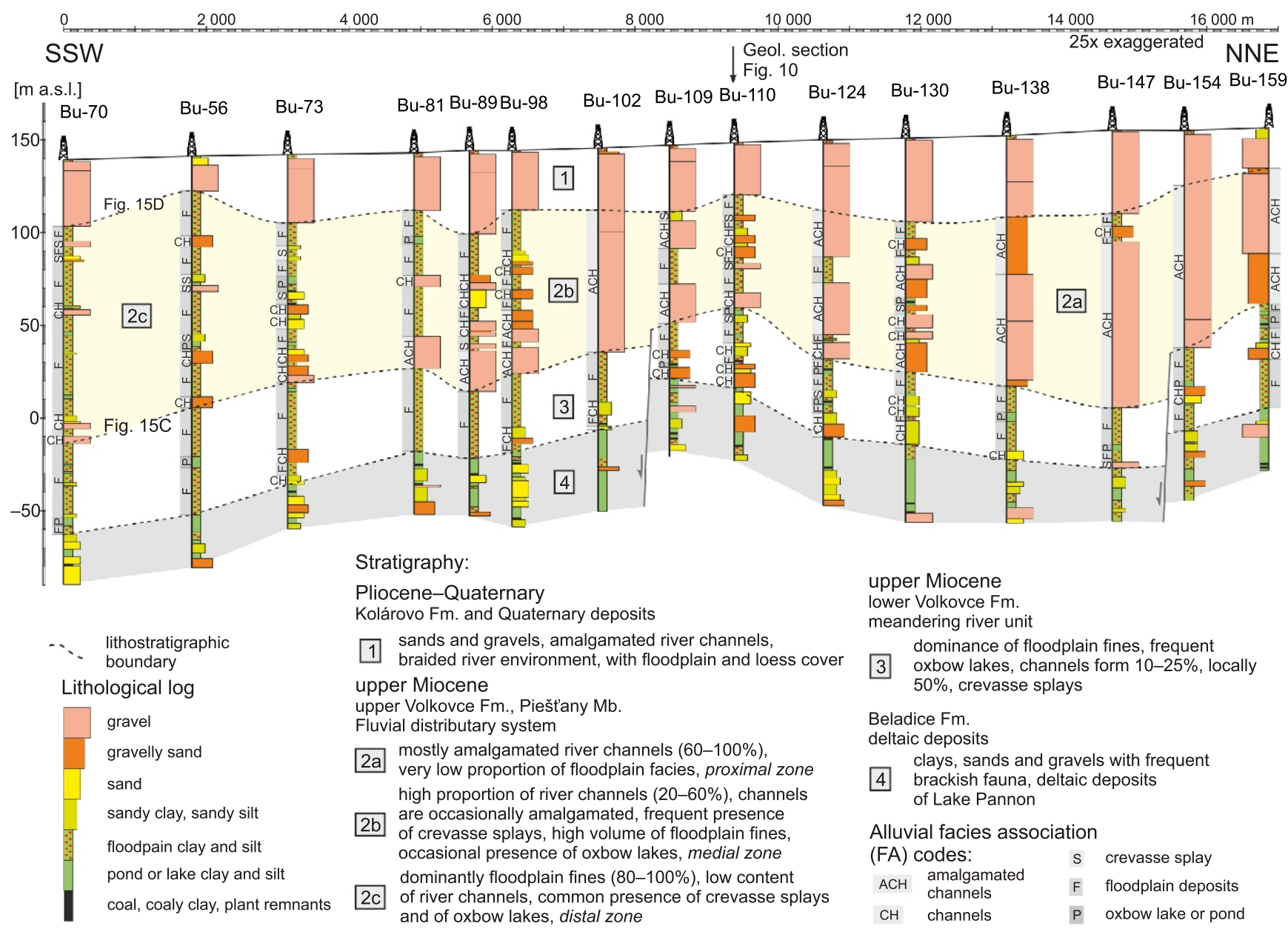

Fig. 8. Geological section oriented in a NNE-SSW direction

Note the lateral lithological transition in the upper Volkovce Formation - Pieštany Member; for location see Figure 3

Planorbis sp., Unio sp.) and terrestrial mollusc species (e.g., Carychium sp., Isognomostoma sp.). Coal layers and coaly clays occur rarely. Sandy-gravelly bodies are usually 7 to $15 \mathrm{~m}$ thick (Figs. 8-10). Sandy gravels frequently have a reddish sandy-clayey matrix.

An increase in the amount of sandy and gravelly lithotypes can be observed in the northern part of the depression (Fig. 9; boreholes Pie-22, Pie-40, Pie-39, Pie-37, Bu-144) and in its eastern part (Fig. 10; boreholes Bu-110, Bu-115, Pie-15, Pie-14, Pie-13). The thickness of the unit is uniform ( 40 m; Fig. 8) and (40-60 m; Fig. 10), while it increases to $100 \mathrm{~m}$ towards the central part of the Blatné depression (Fig. 9).

The well-log pattern of the sequence is mostly serrated with low amplitude, with only minor deflections (e.g., Rat-1, Mad-7; Fig. 11). Upwards fining bell-shaped trends can be observed in boreholes Mad-4, Mad-1 and Mad-5; however, a 35 m thick upwards fining pattern appears in borehole Mad-6 (Fig. 11).

I n t e r p re t a t i o n. - Four facies associations according to Miall (2006) and Campo et al. (2016) were distinguished in this contribution (Fig. 7). The dominant facies in the lower Volkovce Formation comprises terrestrial clays and silts, deposited from suspension on a floodplain facies association $(F)$. Subaquatic clays of grey to blue colours are minor, indicating the occasional presence of oxbow lakes or ponds $(P)$ preserving plant detritus, considered as coal layers. The sandy and gravelly bodies could be interpreted as channel belts $(\mathrm{CH})$. Sandy units a few metres thick are considered as crevasse splay deposits (S). From the proportion of in-channel and overbank deposits, the sequence described probably represents a meandering river environment (Bridge and Diemer, 1983). The upward fining trends in well logs indicate point bar deposits of the channels. The meandering river environment is suggested also by a good lateral continuity of channel bodies between boreholes, which commonly exceeds $2.5 \mathrm{~km}$. The average width/thickness ratio $>200$ reveals a high degree of the lateral migration of a river channel (Gibling, 2006). However, there are no correlative exposures for proving the depositional processes by facies analysis. The distribution of coarse deposits in the northern and eastern parts of the area implies a possible main course of the distributaries.

\section{UPPER VOLKOVCE FORMATION - FLUVIAL DISTRIBUTARY SYSTEM}

D e s c ription. - The facies assemblage of the $\mathrm{N}$ and NE zone (the proximal zone) is characterized by a continuous succession of gravels and/or sandy gravels, only occasionally supplemented by sands and rare variegated and brown clays (Fig. 7). Its content of coarse lithotypes varies between 100 and $60 \%$, and usually is $\sim 90 \%$ (Fig. 12). The thickness of the upper Volkovce Formation in this zone attains $80-100 \mathrm{~m}$. The proxi- 

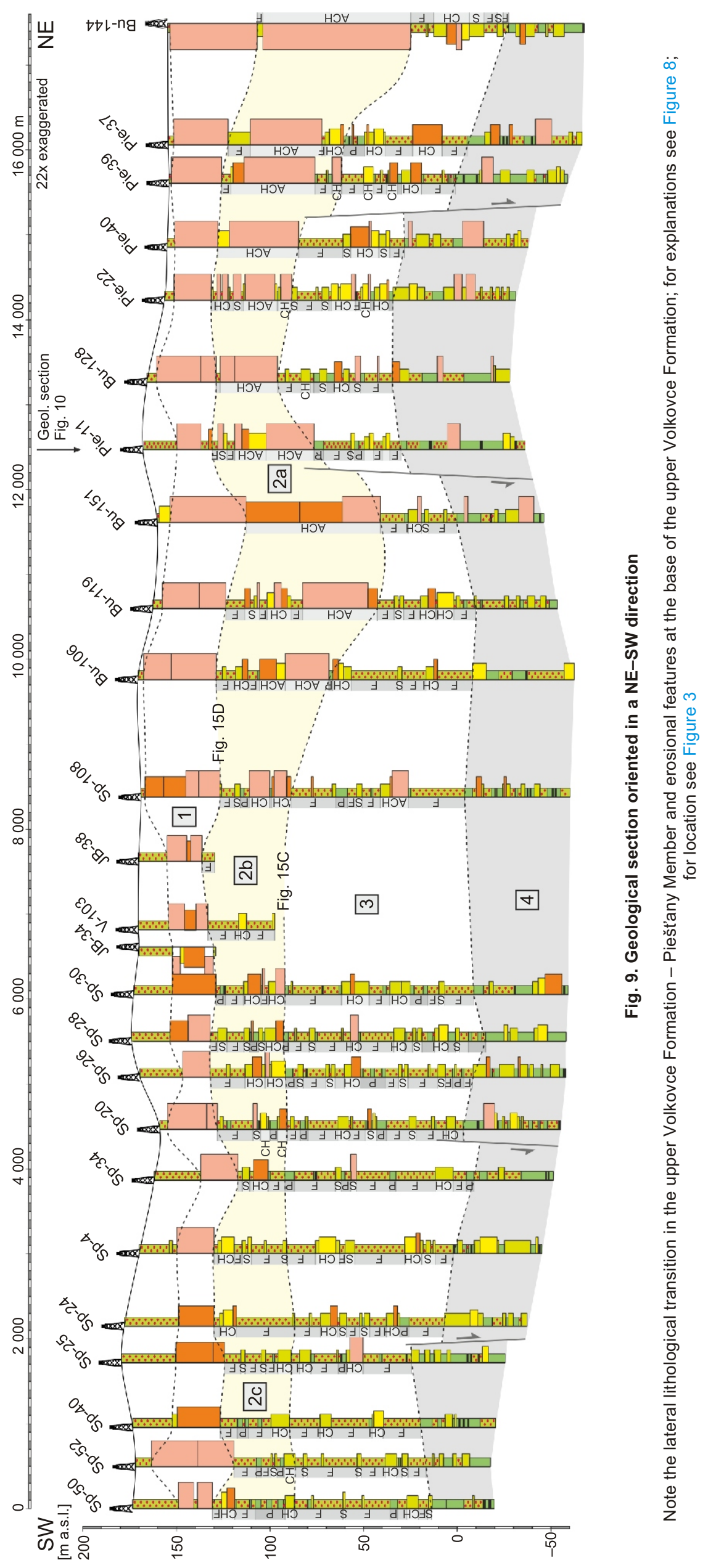


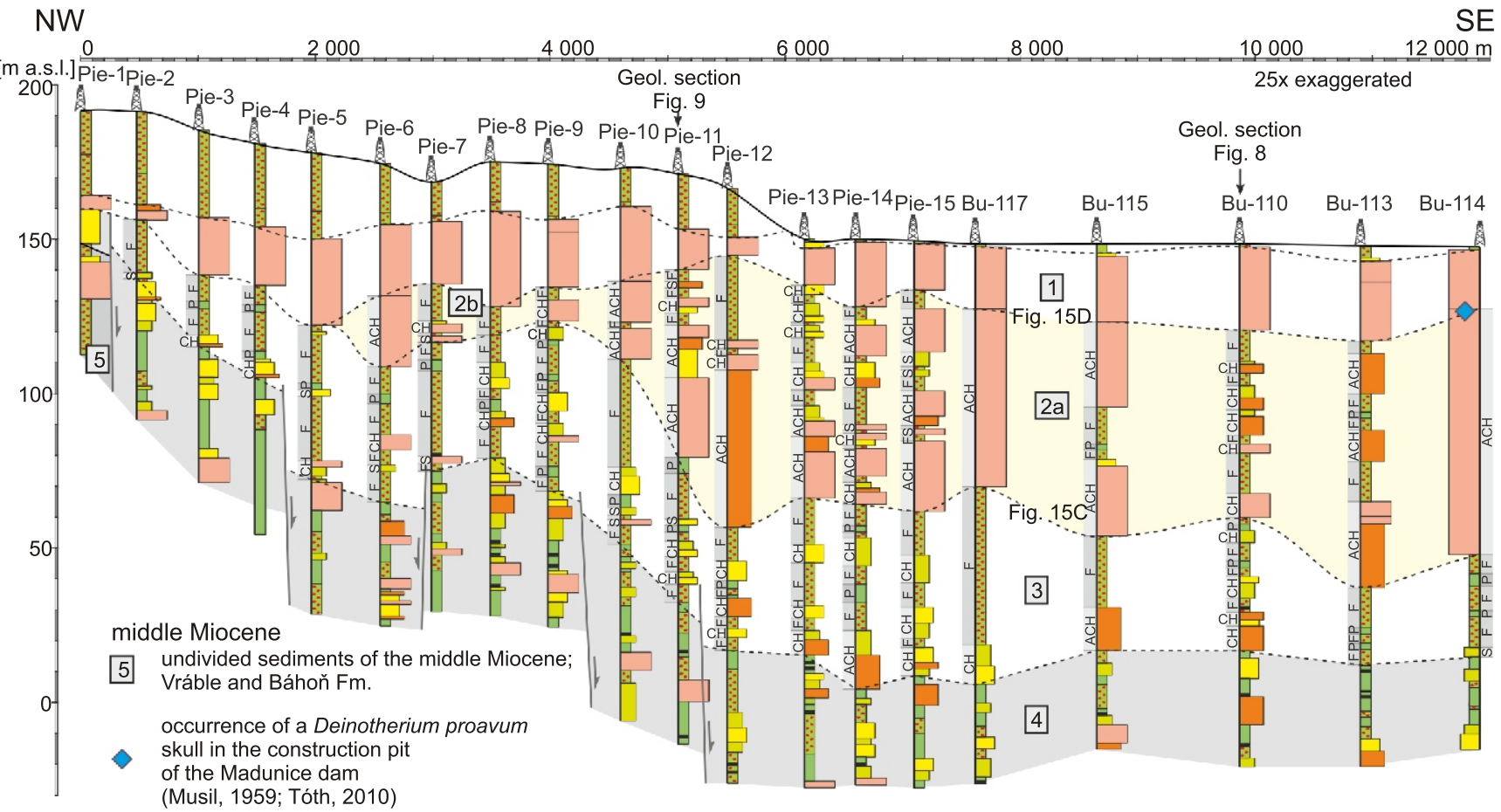

Fig. 10. Geological section oriented in NW-SE direction

Note the asymmetry of the depicted basin fill; for location see Figure 3; for other explanations see Figure 8

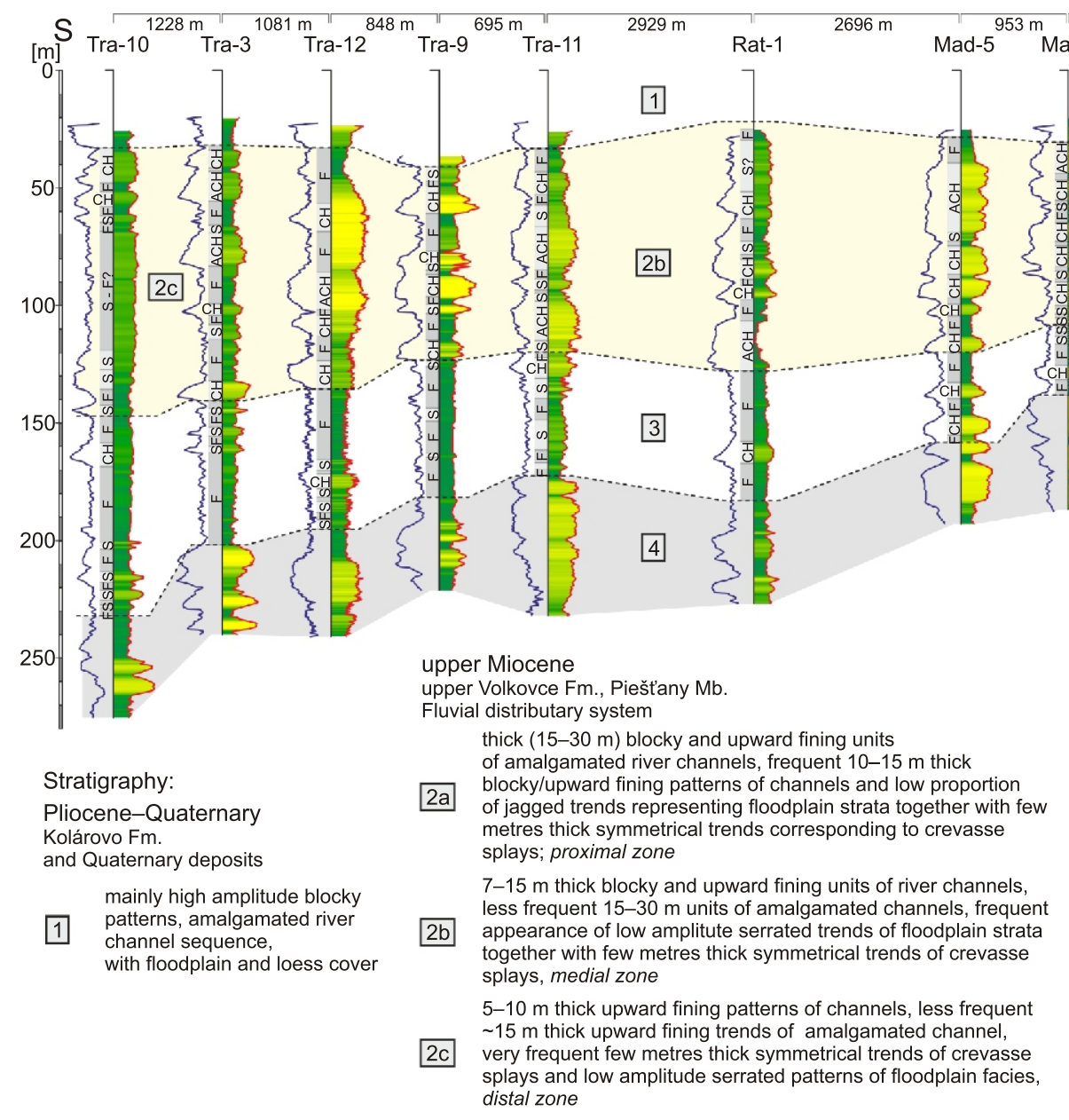

Fig. 11. Correlation scheme of well-log electrofacies oriented generally in NNE-SSW direction 


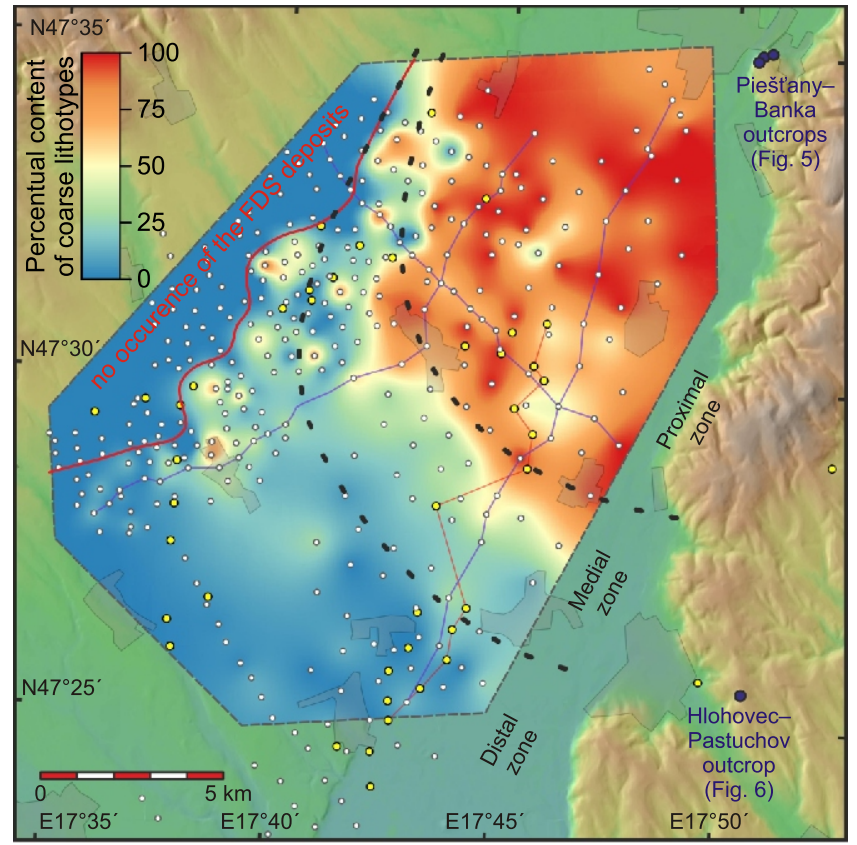

Fig. 12. Map of percentual proportion of coarse-grained lithotypes (gravels, sands with gravels, sands) in the fluvial distributary system (upper Volkovce Formation) in the Blatné depression

Zonation of FDS is defined by distribution of different associations of lithofacies; other explanations as in Figure 3

mal zone reaches a width of at least $13 \mathrm{~km}$ in the study area, but probably extends farther to the north.

The proximal zone passes into a relatively narrow medial zone of tangential shape, the width of which does not exceed $6 \mathrm{~km}$ (Fig. 12). This zone typically has a $60-20 \%$ content of coarse lithotype layers in its succession with several local exceptions (Figs. 8-10). The zone consists of gravelly and sandy bodies $5-10 \mathrm{~m}$ thick. Thin (a few metres) layers of coarse deposits are not common in this zone. Fine-grained lithotypes comprise dominantly brown and variegated clays/silts, while grey to blue clays/silts are rare. The medial zone attains a thickness of 40 to $100 \mathrm{~m}$ and it frequently occurs in areas of lesser thickness of the upper Volkovce Formation (cf. Figs. 8-10).

The SW part of the study area is occupied by the distal zone, which typically has no more than $20 \%$ of coarse layers (Figs. 8-10). The main part of the succession is represented dominantly by brown, variegated and less common grey to blue clays/silts. Sandy and gravelly layers are rare (cf. Fig. 7). The distal zone reaches a thickness of $80-100 \mathrm{~m}$. Terrestrial and freshwater molluscs are occasionally reported in this zone (Lunga, 1964a, 1966).

The well-log record of the electrofacies for the proximal zone in the NE area is mainly represented by upwards fining cycles and blocky patterns, while the serrated pattern forms $<35 \%$ (Fig. 11; between boreholes Mad-4 and Mad-5). The thickness in the range of 20-30 $\mathrm{m}$ of each individual sedimentation cycle was determined based on the observed pattern of the signal. The medial zone is represented by boreholes Rat-1 and Tra-11 (Fig. 11). In the distal zone there is noticed an increase in the serrated pattern and symmetrical to bell-shaped trends. Thus, the lateral transition of the upper Volkovce Formation was documented as well. The upwards fining trend of the SP curve in borehole Tra-12 at a depth of $50-80 \mathrm{~m}$ is considered as unreliable due to a discrepancy with the lithology of neighbouring boreholes (Fig. 11).
Interpretation. - It was demonstrated by facies analysis of the succession that in-channel deposition of stacked braided river channels dominated in the proximal zone, while meandering channels and floodplain deposition is attributed to the distal zone. The lateral transition of facies composition in the borehole record corresponds well to the transition in alluvial depositional features inferred from the outcrops. Five facies associations were distinguished in the upper Volkovce Formation, including the amalgamated channels $(\mathrm{ACH})$, beside the four ones mentioned above $(\mathrm{CH}, \mathrm{S}, \mathrm{F}, \mathrm{P})$.

The change from the almost $100 \%$ gravelly and sandy-gravelly proximal zone to the distal zone with $10-15 \%$ sandy and gravelly layers on average among predominant floodplain facies implies a strong decrease in the transport capacity of the palaeo-stream. A radial character of this transition and increase in proportion of overbank facies in the distal zone suggest that the upper Volkovce Formation was deposited by a fluvial distributary system (FDS; Nichols and Fisher, 2007). The palaeomargin of the basin, where the apex of the distributary system was situated, is hard to locate due to a lack of sufficient data and because the succession was partially eroded towards the north of the study area during the Pliocene and/or Quaternary.

Although the sedimentary sequence in the proximal zone is usually homogeneous lithologically in boreholes, well log patterns imply the presence of individual $20-30$ m thick units, which are considered to represent amalgamated channel cycles. Floodplain facies are more common in the uppermost part of the proximal zone, indicating some upward decrease of coarse sediment supply. The low width of the medial zone indicates a rapid decrease in transport capacity or change in orientation of distributaries. Significantly, this lateral transition is vertically stacked in the same place during deposition of the Piešt'any Member. Sheetflood sandy and gravelly deposits of debris flows, which are expected to occur in the medial to distal zones of FDS (Nichols and Fisher, 2007), are not a common element and coarse-grained lithotypes are limited to the channel belts. Overbank fines (brown and variegated with calcareous nodules and ferric mottles) dominate in the composition of fine-grained lithotypes of the medial and distal zones, while pond or oxbow deposits (grey to blue fines) are rare.

The facies associations of the distal zone, representing a meandering river, are very similar to those of the underlying lower Volkovce Formation. Therefore, the position of the boundary between the successions is, at the southern margin of study area, locally questionable.

Beside these characteristics, an obvious asymmetry of the FDS body studied could be observed (Fig. 12). The shape of FDS indicates that sedimentation occurred also on recently uplifted flanks of the Považský Inovec Mountains. This is supported by appearance of the Pieštany Member at the surface and directly above the pre-Cenozoic complexes (cf. Fig. 3). The uplift of the Považský Inovec Mountains to their recent position took place mainly during the Late Pliocene and Quaternary (Kováč et al., 2001; Sliva et al., 2002).

\section{STRATIGRAPHIC ARCHITECTURE OF THE VOLKOVCE FORMATION IN THE WESTERN RIŠŇOVCE DEPRESSION INFERRED FROM BOREHOLES}

The asymmetric shape of the FDS structure in the northern Blatné depression and its position above the pre-Cenozoic of the Považský Inovec Mountains together with palaeoflow directions in the Pieštany-Banka outcrops indicate that the general direction of palaeotransport might have been confined by the el- 
evated northern portion of the Považský Inovec Mountains. After the flow passed along the horst, the main sediment transport may have been diverted to the SE in the direction of the Rišňovce depression.

In order to investigate whether the main direction of transport of FDS in the northern Blatné depression was towards the SE and crossed over the gentle basement uplift of the Považský Inovec Mountains, 65 lithological logs of water exploration wells and six CF boreholes were obtained from the western Rišňovce depression (Fig. 13). The proportion of coarse lithotypes (gravels, sands with gravels, sands) was calculated for each well which penetrated the Volkovce Formation (Fig. 13A).

$\mathrm{D}$ e s c r i p t i o n. - The thickness of the Volkovce Formation is $180 \mathrm{~m}$ in the area of Hlohovec, where it is situated above pre-Cenozoic granites (Fig. 13B; well HGH-2), and reaches up to $550 \mathrm{~m}$ in the CF boreholes of the Vel'ké Zálužie succession located near the village of Lukáčovce (cf. Figs. 13 and 14). A lithological zonation in the boreholes examined could be deduced based on the proportion of sandy/gravelly units in alluvial sequence.

The area to the NE of the village of Dolné Trhovište is characterized by a small proportion of coarse lithotypes $(0-20 \%$, exceptionally $20-30 \%$ ). The boreholes with the lowest proportion are situated near surface outcrops of the Hlavina Member in the foothills of the Považský Inovec Mountains. The coarse lithotypes are represented mainly by sands forming 4 to $8 \mathrm{~m}$ thick bodies, while gravels are not common. Most of the lithological profiles are composed of variegated and light brown clays/silts with calcareous nodules and ferric mottles (Fig. 13B).

The proportion of coarse-grained lithologies in the Volkovce Formation reaches 30 to $50 \%$ and up to $70 \%$ locally in the SW area. Gravelly layers are common in this territory and may form continuous successions that are several tens of metres thick (well HVH-1; Fig. 13B). Thick sandy bodies appear also in the boreholes examined. The lower part of well HGH-2, $\sim 80 \mathrm{~m}$ thick, has a predominantly fine-grained composition. The upper part of the well shows a considerable increase in the coarse lithotypes with presence of gravels (Fig. 13B).

The SE area differs from previously investigated by a considerable thickness of the Volkovce Formation. The alluvial succession could be divided into two units based on the Vel'ké Zálužie CF boreholes (Fig. 14). The lowermost 125-175 m thick unit is finer-grained with $\sim 15 \%$ of sandy units, from which only few exceed $10 \mathrm{~m}$ in thickness. Subaquatic clays are common and together with variegated and brownish clays form most of the succession. The upper unit, up to $375 \mathrm{~m}$ thick, is generally of upwards fining cycles beginning with a common medium to coarse sandy bodies. These sandy units form $\sim 30 \%$ of the lithological profile and are 5-10 m, locally up to $15 \mathrm{~m}$, thick. Gravels as well as subaqueous pond clays are rare. Fine sands form units mostly 2-3 m thick. The transition from the deltaic Beladice Formation to the alluvial Volkovce Formation is marked here by the disappearance of brackish fauna and lignites as well as by a significant decrease in the proportion of sandy-gravelly strata (Fig. 14).

I n t e r p r e t a t i o n. - The Volkovce Formation is considerably thicker in the western Rišňovce depression than in the northern Blatné depression, which suggests a higher late Miocene accommodation rate. A superposition of two units with different proportions of sands and gravels could be correlated with the lower and upper parts of the Volkovce Formation, as in the northern Blatné depression. Regarding the composition of the upper Volkovce Formation shown in Figure 13B, the 5-10 m thick sandy/gravelly units represent channel fills $(\mathrm{CH})$, in accordance with depositional processes documented from exposures (cf. Fig. 6). However, a significant proportion of amalgamated sandy-gravelly channels $(\mathrm{ACH})$ several tens of metres thick were observed close to the western margin of the Rišňovce depression (Fig. 13B). Farther to the south (Fig. 14), the size and percentage of the channel deposits is reduced, but there is still an increase in their presence at the boundary of the two alluvial units. The significant decrease of pond facies $(P)$ from the lower to upper Volkovce Formation may indicate a change from a poorly drained to a well drained floodplain connected with increased sediment input (Fig. 14; Amorosi et al., 2016).

The borehole data described reveal that the main alluvial input of coarse sediments into the western part of the Rišňovce depression could not have come from areas located to the north, where channel-fill lithotypes form only a minor part of the succession. More likely, the stream transporting coarse sediments to FDS in the northern Blatné depression continued near the margin of the Považský Inovec morphostructure towards the SE and deposited a sandy-gravelly alluvial succession in the SW Rišňovce depression. This palaeogeographic scenario might also explain the narrow character of the medial FDS zone in the northern Blatné depression and the relatively sharp transition to fine-grained sedimentation towards the south (Fig. 12).

The Volkovce Formation palaeotransport direction varied towards SW and SE in the Rišňovce depression (Törokövá, 1999; Kováč et al., 2001, 2006; Sliva et al., 2002). Sedimentological logs of the exposures show that cross-stratification does not reach a thickness $>30 \mathrm{~cm}$, and usually vary between 10 to $20 \mathrm{~cm}$ (Törokövá, 1999). The expected palaeoflow depth therefore reached no more than $1.8 \mathrm{~m}$ (Leclair and Bridge, 2001). There is furthermore only $<20 \%$ proportion of channel lithofacies in the lithological profile of the northern part of the Rišňovce depression. These observations suggest that there were only small river streams with a low supply of sediment in this area between $10.0-6.5 \mathrm{Ma}$. They merged with the sediment-laden streams flowing from the Blatné depression in the area between Hlohovec and Klačany (Fig. 13A).

\section{GEOMETRY OF THE FDS STRUCTURE AND MORPHOLOGY OF THE STRATIGRAPHIC SURFACES}

There are a number of factors that may influence the morphology of a stratigraphic surface in alluvial deposits: the initial topography of the substrate connected with possible base-level fall and development of incision features during deposition, differential sediment loading, differential compaction of the underlying strata, tectonic subsidence and faulting after deposition (e.g., Miall, 2000; Catuneanu, 2006). To investigate the influence of these factors, four contour maps of the northern Blatné depression were constructed (Fig. 15). These maps show the following stratigraphic boundaries of erosive origin: the base of the Cenozoic (Fig. 15A), the basal surface of the upper Miocene (Fig. 15B), the basal surface of the studied FDS of the Pieštany Member (Fig. 15C), and the basal surface of the Pliocene-Quaternary sequence, which overlies the studied FDS (Fig. 15D). The first surface was constructed using deep borehole data obtained from Biela (1978) and archive data of seismic reflection (Vašek et al., 1961; Pavelka et al., 1963; Vejrostová and Adam, 1964; Beinhauerová et al., 1969). The next three surfaces are based on CF borehole data. A fault pattern disrupting the base of the upper Miocene is inferred from structural maps of oil surveys (Pavelka et al., 1963; Vejrostová and Adam, 1964; Pagáč, 1965; Lunga, 1968; Beinhauerová et al., 1969).

The base of the Cenozoic is disrupted by faults oriented in a NE-SW direction (Fig. 15A). They are probably connected to an important transtensional fault system, the activity of which led to accumulation of a middle Miocene succession up to $3 \mathrm{~km}$ thick 


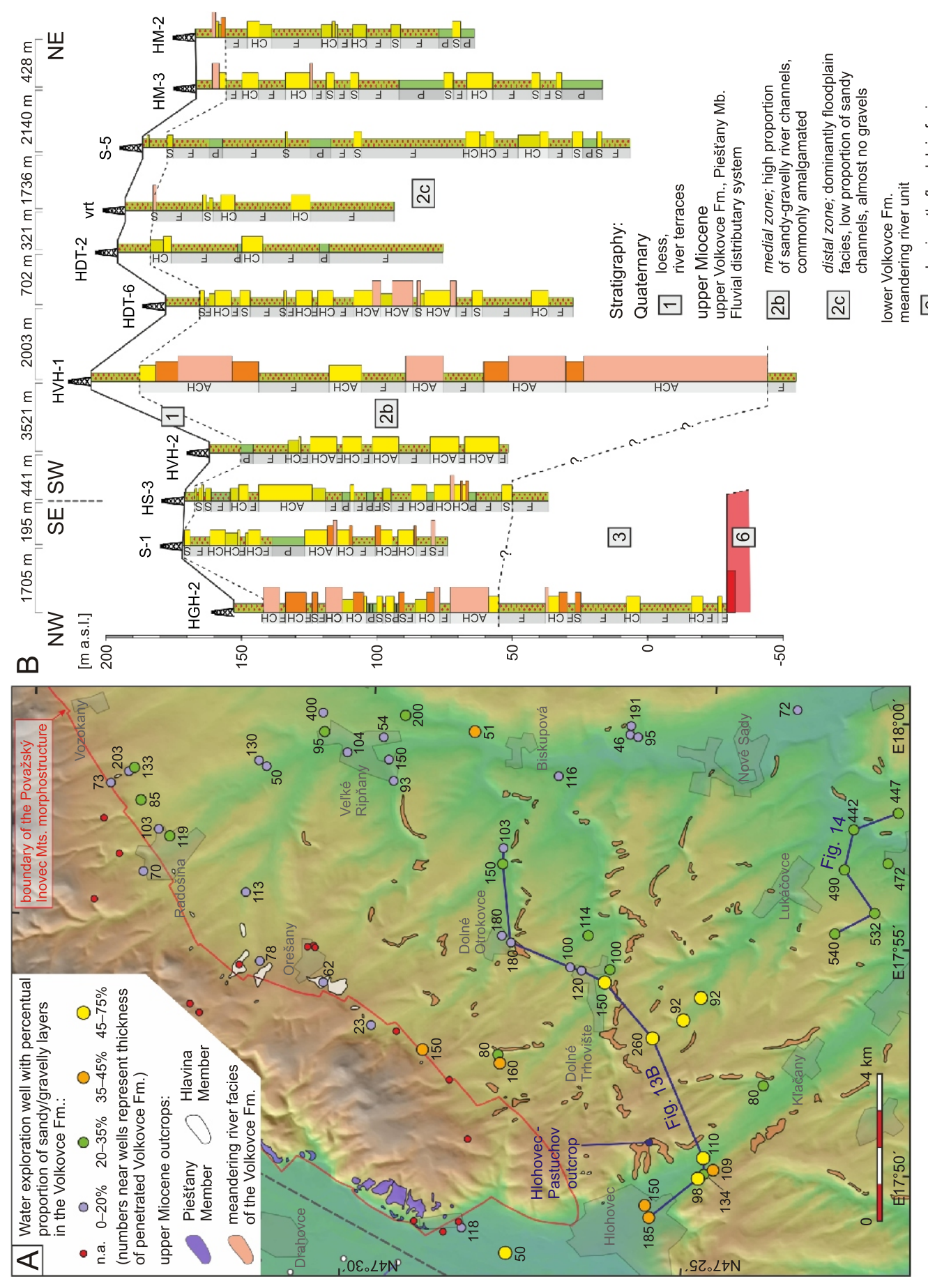

$\frac{1}{\pi} \cdot \frac{1}{0} \cdot \frac{0}{0}$

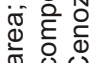

幽.

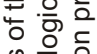

온응 웅

는

z

它

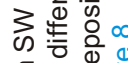

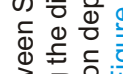

定.

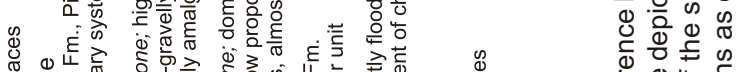

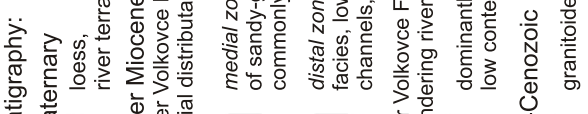

흥

बis

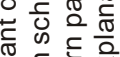

岑. 등

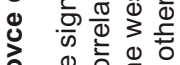

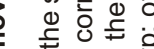

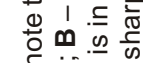

类

要言需。

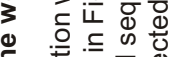

\pm 㱐

을 음 윤

䒕

西党要

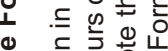

ذั

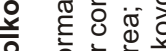

政市

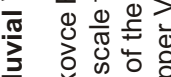

言

品

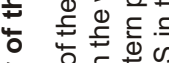

ते

흔

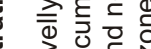

क तٓ

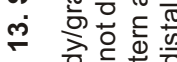

क्षे

施

등하융

항

응눈

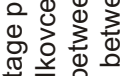

它 응

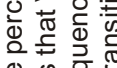

o

일

垟

唁

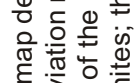

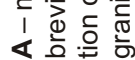




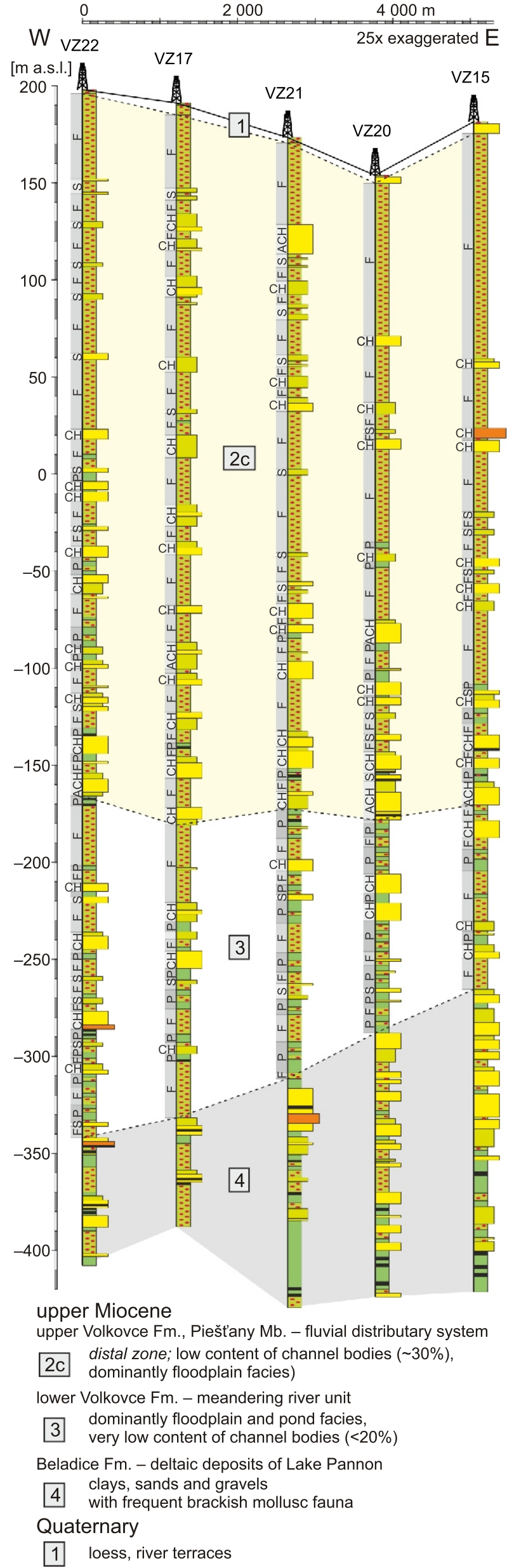

during the syn-rift subsidence in this part of the basin (Kováč, 2000; Rybár et al., 2015, 2016). The base of the Cenozoic is asymmetrical with a more elevated NE margin. The main depocenter is situated in the SE part of the study area. The altitude differences between the margins of the study area and the central depocenter reach $>3000 \mathrm{~m}$, while offsets on faults increase from 300-500 $\mathrm{m}$ in the NE to $1000 \mathrm{~m}$ in the SW (Fig. 15A).

The base of the upper Miocene was disrupted by a fault system, which had already been identified by Pagáč (1965), Lunga (1968) and Beinhauerová et al. (1969; Fig. 15B). The identification of faults was based on seismic surveys and correlation of counter-flush and deep structural boreholes. The dominant orientation of the corresponding faults is NE-SW and N-S. These structures are probably connected to transtensional faults, which caused the middle Miocene subsidence. The offsets of these faults reach 30 to $60 \mathrm{~m}$ in the central part and up to $130 \mathrm{~m}$ in case of faults which bound the NW margin (Fig. 15B). The shape of the surface is asymmetrical with a more elevated NW margin. It differs from the pre-Cenozoic base and is similar to the overlying base of FDS (cf. Fig. 15C). The SE margin of the accommodation space is also clearly identifiable. A depression may be observed in the northern part of the area. The shape of the main depression is elongated in a NE-SW direction. The declination of the upper Miocene base is oriented towards the SW, where is situated the maximum of the thickness of the upper Miocene sequence in the Blatné depression (Fig. 15B).

It may be concluded that the base of the fluvial distributary system of the Pieštany Member is a highly asymmetrical surface, with an elevated NW margin, where FDS sequence thins out (cf. Figs. 10 and 15C). The asymmetry is comparable to that of the base of the upper Miocene (cf. Fig. 15B). In contrast to the upper Miocene base, there is no evidence of a slope along the SE margin of the surface situated directly along the Považský Inovec Mountains. As previously mentioned, this indicates that the pre-Cenozoic morphostructure of the Považský Inovec Mountains was a part of the accommodation space of FDS, in accordance with the geometry of the FDS zones (cf. Fig. 12). Furthermore, the basal surface of the FDS succession has two linear depressions generally oriented NNW-SSE, with a 50 to $70 \mathrm{~m}$ altitude difference with respect to the surrounding areas (Fig. 15C). These depressions have a gradually deepening morphology. Their orientation is perpendicular to the faults affecting the base of the upper Miocene. The base of FDS declines overall towards the southern margin of the area studied. This is in contrast with the shape of the main depocenters of the upper Miocene base and the Cenozoic base (cf. Fig. 15A-C).

The greatest similarity between the two depressions (located in the middle and NE areas) is clearly visible when comparing the palaeosurfaces of FDS base with the Pliocene-Quaternary one (Fig. 15C, D). These depressions, although of much lower altitude difference, are located in very similar positions. They are oriented in a NW-SE direction and they are separated by a broad flat area trending from NE to SW. It is bound by a linear depression from the SW and then comes from the NW as a flat area, representing a river terrace. By analogy with the base of FDS, the Pliocene-Quaternary base is asymmetrical with an elevated NW margin and a declination towards the SE (Fig. 15D).

\section{Fig. 14. Geological section located in the central part of the Rišňovce depression}

Note the large thickness of the Volkovce Formation; the boundary between the Beladice Formation and the Volkovce Formation is inferred from facies change, disappearance of brackish mollusc fauna and of coal (lignite) layers, while the transition between the lower and upper Volkovce Formation is based on increase in channel FA frequency and the occasional presence of amalgamated channels 

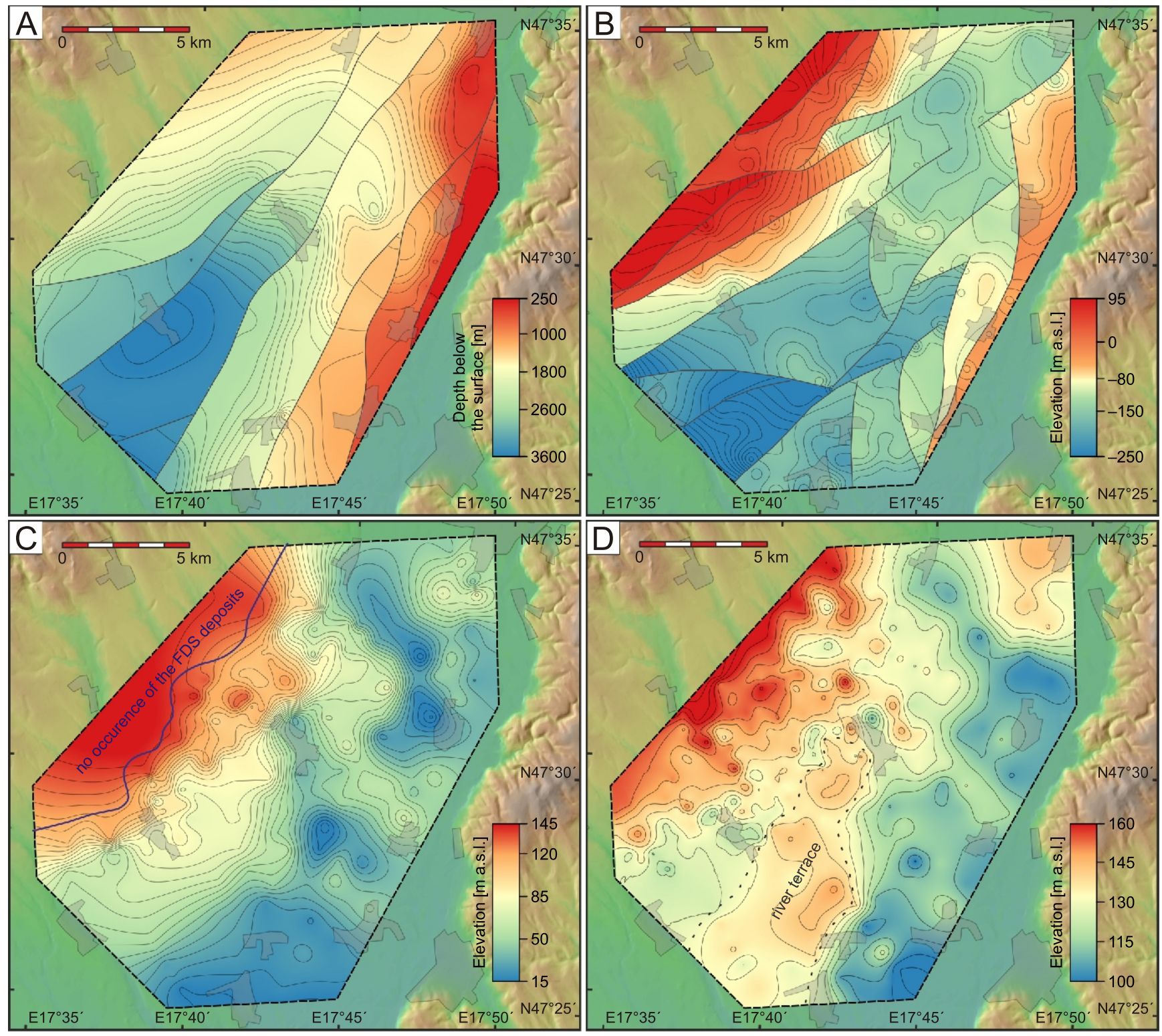

Fig. 15. Structural maps of selected stratigraphic surfaces in the northern Blatné depression

A - basal surface of the Cenozoic basin fill; contour interval $100 \mathrm{~m}$; B - basal surface of the late Miocene succession, with faults interpreted according to correlation of wells and structural maps of Pagáč (1965), Lunga (1968) and Beinhauerová et al. (1969); contour interval 10 m; C - basal surface of the FDS succession; contour interval 5 m; D - basal surface of the Late Pliocene and Quaternary braided river gravelly-sandy unit; contour interval $5 \mathrm{~m}$

\section{INTERPRETATION OF FACTORS CONTROLLING THE VOLKOVCE FORMATION DEVELOPMENT}

DEPOSITIONAL ENVIRONMENT OF THE VOLKOVCE FORMATION AND PALAEOCLIMATE

Climate affects the river regime directly through precipitation intensity and its distribution throughout the year, by temperature regime, which is connected with erosion intensity and sediment supply, and indirectly through the density of vegetation, which affects both sediment supply and intensity of lateral channel migration (Miall, 1983). Therefore, climate is a major driving factor of depositional processes.

A continuously channelized braided river environment with no sheetflood facies was determined for the proximal zone of
FDS in the Piešt'any Member during its deposition 9-8 Ma. It is interpreted as a perennial flow regime, which indicates a stable discharge in relatively humid climate. A sedimentary succession of age 6.5-6.0 Ma was described in distal zone of FDS as a meandering river channel belt. Fossil roots were documented in the outcrop in the lower part of the inclined heterolithic stratification - IHS (cf. Fig. 6). This indicates a permanently high ground-water level, probably associated with a humid climate and high accommodation rate (McCarthy et al., 1998; Retallack, 2001). The record of cyclic sedimentation in IHS unit with frequent erosional surfaces implies high discharge typical of perennial rivers in a humid climate (Thomas et al., 1987).

Some decrease in river discharge could be inferred from more frequent floodplain strata in the uppermost part of the proximal and medial FDS zones (cf. Figs. 8 and 9). Generally, it can 
be concluded that the depositional environment studied lasted in humid conditions until the early Messinian, i.e. $~ 6.0 \mathrm{Ma}$.

\section{SEDIMENT SUPPLY - ACCOMMODATION RATE INTERACTION}

The stratigraphic model of depositional environments interpreted for the Volkovce Formation at $\sim 8 \mathrm{Ma}$ is shown in Figure 16A. A strong spatial variation in thickness of the Volkovce Formation and variation in distribution of channel deposits was also demonstrated. Generally, the northern Blatné depression shows four times lower accommodation than the western Rišňovce depression (Fig. 16B, C). However, the main source of sediment supply was located to the $\mathrm{N}$ of the northern Blatné depression and only amalgamated channel fills were preserved there because of low accommodation rate. The palaeotransport was affected by a topographic barrier formed by the pre-Cenozoic rocks of the northern Považský Inovec Mountains (Fig. 16B). The northern Považský Inovec Mountains were exposed only as a low topography elevation, which restricted significant input of sediments (Fig. 16A). The southern part of the mountains was slowly subsiding, which allowed FDS to cross the barrier between the two depressions towards the area of much higher subsidence (Fig. 16C). The difference in subsidence had to be high enough to form a topographic gradient (Hickson et al., 2005). The submerged part of the Považský Inovec Mountains acted as a boundary between areas with low and high accommodation rates and therefore a transition between braided and meandering river environments took place there. Rapid subsidence was compensated by intense sediment supply in the Rišňovce depression, which led to preservation of both the thick overbank and channel belt deposits (Fig. 16C).

BASE LEVEL FALL, TECTONIC MOVEMENTS AND CAUSES OF DIFFERENTIAL SUBSIDENCE

The orientation of the two linear depressions at the base of FDS is perpendicular to the faults described for the bases of the Cenozoic and upper Miocene (Fig. 15A, B). However, there is no significant correlation between these depressions and the morphology of the late Miocene base. This means that these depressions were not formed by normal fault activity.

These linear depressions are parallel to the inferred palaeotransport direction towards the Rišňovce depression. Hence, it is expected that the depressions were formed during an erosional phase, which generated slightly incised valleys. The incised topography led to confinement of the fluvial distributary system. On the other hand, the correlative stratigraphic boundary is not of erosive origin in the Rišňovce depression. Hence, it appears probably as a correlative conformity caused by more rapid subsidence (Fig. 16C).

The erosional phase resulted from base level fall. However, the water level drop of Lake Pannon could not be the main reason, because this lake was too far distant at the time $\sim 9 \mathrm{Ma}$ (cf Fig. 1B; Magyar et al., 2013; Šujan et al., 2016). Differential subsidence along the stream documented between the Blatné and Rišňovce depressions is a prominent candidate as a driving factor. Uplift of the northern Blatné depression may also have been responsible for this incision. Tectonic activity during 9-8 Ma is indicated by the deposition of the freshwater carbonates of the Hlavina Member along marginal faults of the Považský Inovec Mountains.

This spatial variability in subsidence could have been generated not just by tectonics but also by differential compaction of the underlying deposits. A varied thickness of progressively compacting sequences exerts a first-order control on recent subsidence, for example, in the coastal area of the Netherlands (Kooi, 2000), as well as on the development of the Late Cenozoic Niger delta (Fazli Khani and Back, 2015). Gvirtzman (2001) determined a dependence between spatial variability of sediment thickness and associated difference in amount of compaction-related subsidence. In the case of the middle Miocene sequence, which is $\sim 3 \mathrm{~km}$ thick in the central part of the Blatné depression and only a few hundred metres thick at its margin (Fig. 15C), compaction should produce two to three times higher subsidence in the central part of the depression during the late Miocene.

However, FDS sequence thickens towards the SE, i.e. in the direction in which the basin fill abruptly thins (Figs. 10 and 15C). It is important to consider the erosion phase, which is expected to have occurred at the middle-late Miocene boundary (Horváth et al., 2006). The Sarmatian (late Serravallian) deposits were completely removed from several parts of the area studied during this interval. This means that there was exhumation and subsequent reburial during the late Miocene. Therefore, the basin fill may have been over-compacted, depending on the unknown thickness of the eroded sequence (Gvirtzman, 2001), and consequently compaction did not contribute to the late Miocene subsidence rate.

The Pliocene-Quaternary base is characterized by the presence of depressions situated at the base of FDS (Fig. 15C, D). Gravelly strata have a relatively low compaction potential by comparison with clays and a significantly higher density than uncompacted clays (Garga and Madureira, 1985; Rücknagel et al., 2013). Therefore, it may be expected that the mostly gravelly body load of FDS in the northern Blatné depression was an influence on the compaction of the underlying upper Miocene strata. This continued to a slight extent after deposition of the Pliocene-Quaternary sequence. Thus, this process was a minor driving factor of the present stratigraphic architecture.

Generally, normal fault movement of the Ripňany Fault, bounding the western margin of the Rišňovce depression, is identified as the main factor causing the spatial variability of subsidence (Fig. 16B, C; Bielik et al., 2002). Despite faulting in the Blatné depression being negligible, differential vertical tectonic movements caused river incision at $\sim 9 \mathrm{Ma}$ as well as the creation of sandy-gravelly channel belts in the Tortonian-Messinian alluvial sequence studied (cf. Figs. 2 and 16).

\section{DISCUSSION}

\section{GENETIC ZONATION OF THE FLUVIAL DISTRIBUTARY SYSTEM}

Despite the presence of simplistic classifications of fluvial distributary systems (e.g., Stanistreet and McCarthy, 1993), it is widely accepted that depositional processes may vary significantly across FDS (Nichols and Fisher, 2007). A number of studies have shown a transition of depositional processes comparable to the stratigraphic architecture described herein. Evans (1991) reported a humid tropical FDS consisting of gravelly bedload river deposits in a proximal zone, which pass into sandy bedload and mixed load deposits in the distal zone as well as a low content of unconfined gravity flow deposits. Humid conditions on the Po Plain led to development of FDS with a braided pattern in the proximal zone and meandering river deposits in the distal zone during the Quaternary (Ori, 1982). Several recent FDSs of Alaska display a pattern of stacked channels transporting coarse gravel that pass into meandering channels with a high amount of overbank deposits covered by 
A Palaeogeography at $\sim 8 \mathrm{Ma}$

exposed pre-Cenozoic sequences forming low topography

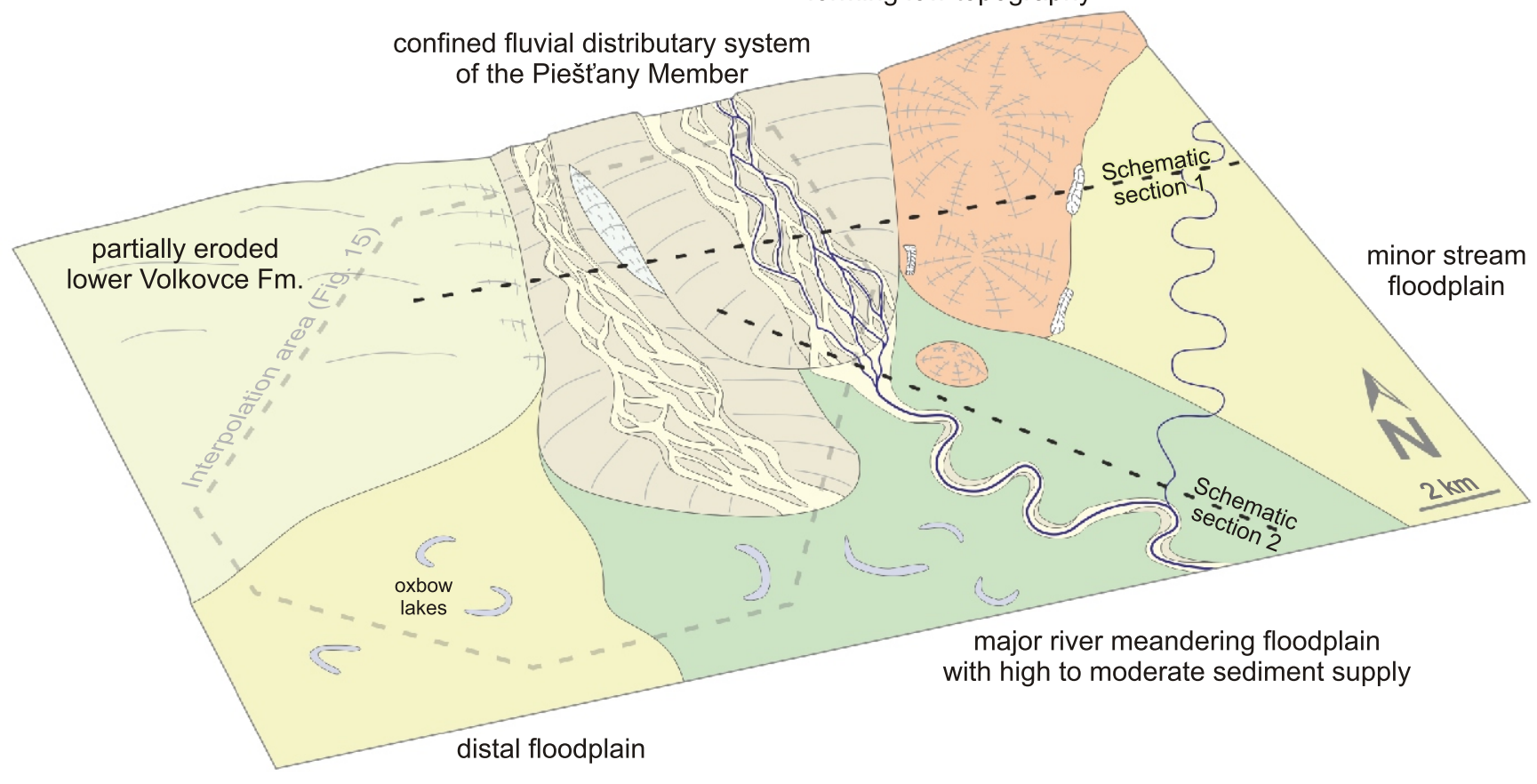

$\begin{gathered}\text { moderate terrain } \\ \text { \& low erosion }\end{gathered}$
$\mathrm{B}$ Schematic section 1
(perpendicular to the general transport direction)

W Blatné depression

Považský Rišňovce

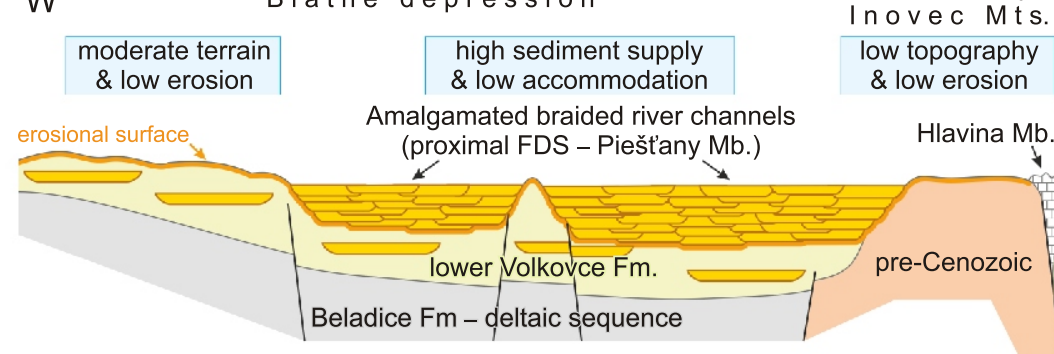

depression

$$
\text { NW }
$$

\begin{tabular}{|c|c|}
\hline $\begin{array}{l}\text { Blatné } \\
\text { depression }\end{array}$ & $\begin{array}{c}\text { Považs ký } \\
\text { I novec } \\
\text { Mts. }\end{array}$ \\
\hline $\begin{array}{l}\text { high sediment } \mathrm{s} \\
\text { \& low accommo }\end{array}$ & $\begin{array}{l}\text { ply } \\
\text { tion }\end{array}$ \\
\hline
\end{tabular}
Partly amalgamated
river Transition of river depositional regimes (medial FDS)

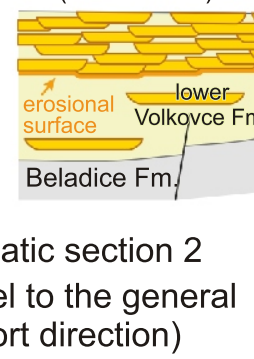

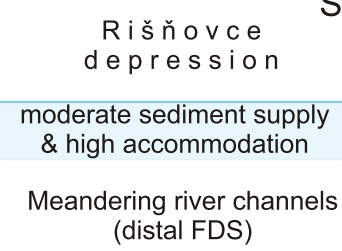
(distal FDS)

SE

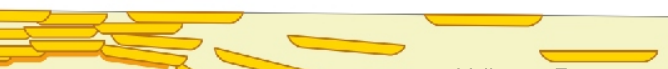
upper Volkovce Fm.

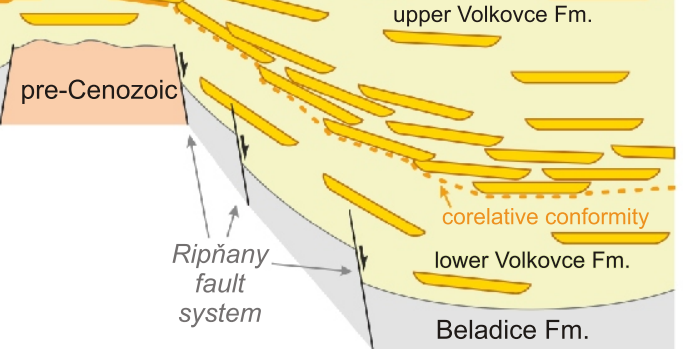

low sediment supply

\& high accommodation

Meandering river channels of small streams
C Schematic section 2 (parallel to the general transport direction)

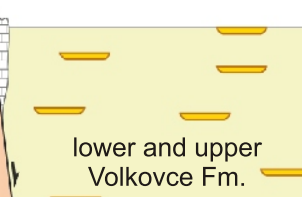

General facies in the Volkovce Fm.:

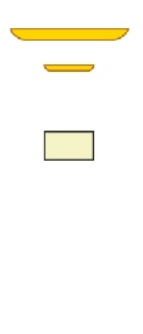

\section{gravelly and sandy channel bodies (large/small)}

floodplain facies, mostly clays and sitls

Fig. 16. Interpretation of the spatial variability of the Volkovce Formation in response to palaeotopography, sediment supply, accommodation rate and fault activity

A - palaeogeographic scheme of the study area for the time period around $8 \mathrm{Ma}$; B - schematic section oriented perpendicular to the palaeotransport direction and to the Považský Inovec horst; $\mathbf{C}$ - schematic section oriented parallel to the palaeotransport direction; note that schematic sections are highly exaggerated vertically 
dense vegetation (Boothroyd and Nummedal, 1978). A meandering river regime is furthermore an important feature of the Late Pleistocene-Holocene Maros fluvial distributary system in Hungary (Kiss et al., 2014).

\section{LATE MIOCENE PALAEOCLIMATE IN THE CENTRAL EUROPE IN THE CONTEXT OF THE ALLUVIAL SEQUENCE STUDIED}

The palaeoclimate varied significantly in the study region during the Tortonian-Messinian interval. A "washhouse" event with mean annual precipitation (MAP) ranging from 1000 to $1500 \mathrm{~mm}$ was documented for the Paratethys realm $\sim 10.0 \mathrm{Ma}$, based on the ecophysiological structure of herpetological assemblages (Böhme et al., 2008, 2011). Comparable values were documented by a wide variety of proxies (Bruch et al., 2006, 2007; van Dam, 2006; Erdei et al., 2007; Kern et al., 2012, 2013). During the following interval between 10.0 and $8.0 \mathrm{Ma}$, MAP in the region decreased to values between $500-1000 \mathrm{~mm}$, and after 8.0 Ma the climate became more arid by comparison with the present day, with a MAP of $\sim 400 \mathrm{~mm}$ (Böhme et al., 2011). Van Dam (2006) deduced a decrease in MAP from $\sim 800 \mathrm{~mm}$ at around 8.0 Ma to $\sim 600 \mathrm{~mm}$ at around $6.0 \mathrm{Ma}$, based on small mammal associations. Comparable decrease in MAP was documented in the northeastern Carpathians (Syabryaj et al., 2007). However, Utescher et al. (2017) argue that the MAP inferred for the central Pannonian Basin System from fossil macroflora point to almost no decrease between 8.0 to $6.5 \mathrm{Ma}$ with values ranging from 850 to $1300 \mathrm{~mm}$. The climate in the region became more humid during the Pliocene with a MAP between 700 and 1400 mm (Kovács et al., 2015). Mean annual temperature (MAT) for the Tortonian age was suggested to be in the range $15-17^{\circ} \mathrm{C}$ (Prista et al., 2015). By comparison, recent MAP in the region ranges usually between 500 and $600 \mathrm{~mm}$ and MAT reaches 9-11 ${ }^{\circ} \mathrm{C}$ (Melo et al., 2007, 2013).

Depositional settings documented in our study indicate humid conditions for time interval 9-6 Ma, with no evidence for decrease of precipitation. Inconsistency with data published by Böhme et al. (2011) and van Dam (2006) may be connected with their spatial distribution of studied localities with no information about the Danube Basin. Its microclimate might have had different MAP during early Messinian, still affected by the water body of Lake Pannon and comparable to the data of Utescher et al. (2017). Lower but notable variability of recent microclimate is still present in the region (e.g., Niedźwiedź et al., 2009; Anders et al., 2014). This points to a careful consideration of published general palaeoclimate models for local studies.

\section{REGIONAL LATE MIOCENE PALAEO-RIVER NETWORK} AND TECTONIC DEVELOPMENT

The relatively high sediment supply of the fluvial distributary system studied (Pieštany Member) reaching the northern Blatné depression was derived from the uplifting Western Carpathians. The uplift of this mountain belt during the middle to late Miocene was deduced using thermochronology (Kováč et al., 1994; Danišík et al., 2004; Králiková et al., 2016), but no significant uplift event was described that might have caused the large increase in sediment supply at $\sim 9 \mathrm{Ma}$. We suggest that this increase in sediment supply was a result of both the higher mean precipitation at $\sim 10 \mathrm{Ma}$ (e.g., Böhme et al., 2008), which would have increased erosion rates, and a major change in river basin pattern in the western part of the Western Carpathians that was probably a result of stream capture.

The palaeo-stream, which deposited the studied FDS, represented one of the main distributaries of sandy deposits that came into the central part of the Danube Basin, despite its restricted scale of bankfull depth of up to $4 \mathrm{~m}$. The alluvial Volkovce Formation is strongly dominated by floodplain facies across the basin, which is caused by accommodation rate of much higher intensity compared to sediment supply (Šujan et al., 2016). This highlights that no significant source area appeared uplifted directly at the Danube Basin margin. The palaeo-stream was a tributary to a larger river basin of the palaeo-Danube. This watershed covered, during the late Miocene, an area from the Eastern Alps, through the Molasse Basin, Vienna Basin, Danube Basin towards to the central Pannonian Basin in the south, where the coast of Lake Pannon was present during that time (Frisch et al., 1998; Magyar et al., 2013).

On the other side, several comparable fluvial distributary systems existed during the same time on the foothills of the Eastern Alps, when the Hausruck and Kobernaussen Gravel in the Austrian Molasse Basin (Brügel, 1998; Kovar-Eder and Wojcicki, 2001; Daxner-Höck et al., 2016), and the Rohrbach Conglomerate in the Vienna Basin were deposited (Wagreich et al., 2009). Exhumation of the Eastern Alps is thought to have continued steadily during the late Miocene (Kuhlemann et al., 2006). Deposition of these FDS structures, however, resulted from increased sediment supply, which was probably related to increased vertical tectonic movements similarly to our study area.

The stratigraphic model of the Volkovce Formation offers insight into the late Miocene fault activity in a marginal part of the Danube Basin. The "Wide rifting" sensu Lankreijer et al. (1995) mediated by activity of NNE-SSW to NE-SW-striking faults generated a deep basin with a very large availability of accommodation space in the central Gabčíkovo-Győr depression in the early Tortonian (Marko et al., 1995; Fodor et al., 1999; Kováč et al., 2011). The subsequent phase of thermal subsidence from 9 Ma to the Pliocene (Kováč et al., 2011), was characterized by little fault activity and large-scale flexural deformation of strata across the basin documented by seismic stratigraphy (e.g., Horváth, 1993; Lankreijer et al., 1999). According to the evidence presented in our study, the fault activity was negligible in the period 9.0-6.0 Ma in the Blatné depression. However, the considerable difference in accommodation rate between the Blatné and Rišňovce depressions at that time points to significant activity of the Ripňany Fault system, which limits the Považský Inovec Mountains. from the south-east (e.g., Bielik et al., 2002). The normal fault throw might have reached up to $400 \mathrm{~m}$. We have to conclude that the proposed models, describing a decrease in fault activity after $\sim 10.0-9.0 \mathrm{Ma}$, are valid only locally and significant exceptions occur on the northern margins of the Danube Basin.

\section{CONCLUSIONS}

The study presented demonstrates the stratigraphic architecture of the alluvial Volkovce Formation of late Miocene age in the northern Danube Basin, with special emphasis on the Pieštany Member forming a fluvial distributary system. The study is based on facies analysis of two key localities and on the sedimentary record of $>500$ boreholes. Our attention was focused on the northern Blatné and western Rišňovce depressions, recently separated by the pre-Cenozoic Považský Inovec Mountains. The Volkovce Formation was deposited there after regression of Lake Pannon in the time period between 10.0 and 6.0 Ma (Šujan et al., 2016).

In both depressions, the lower Volkovce Formation comprises a meandering river succession, in which floodplain fines (clays and silts) dominate and channel bodies are distributed ir- 
regularly. This thin sedimentary succession was deposited between 10.0 and $9.0 \mathrm{Ma}$.

A significant spatial variation of the sediment supply and accommodation rate was documented in the upper Volkovce Formation (ranging from 9.0-6.0 Ma) across the study area. A fluvial distributary system (FDS) of the Piešt'any Member accumulated in the northern Blatné depression. Its proximal facies association is composed of cross-stratified gravelly to sandy braided river bars with a normal gradation, indicating a channelized depositional environment with a channel depth reaching up to $4 \mathrm{~m}$. The distal succession of FDS was deposited in a meandering river environment, according to facies analysis of a type outcrop. Trough cross-stratified strata of a sandy bedform pass upwards into inclined heterolithic stratification (IHS) deposited through lateral accretion and are capped by floodplain fines. The palaeochannel depth is inferred to have been up to $3.5 \mathrm{~m}$.

Tracking lateral changes of facies associations in boreholes allowed us to delimit three zones of fluvial distributary system in the northern Blatné depression: the proximal zone on the north with mostly amalgamated gravelly and sandy-gravelly river channels, the relatively narrow medial zone with a balanced ratio of channel and floodplain deposits, and the distal zone on the south-west and south with a channel facies content of $<20 \%$. A high proportion of channel bodies in the proximal zone indicates high sediment supply and low accommodation rate. The spatial distribution of these zones is radial and asymmetrical, indicating that part of the system was deposited above the recently uplifted Považský Inovec Mountains. The transport of sandy/gravelly material was traced in wells towards the Rišňovce depression. It was observed that the alluvial sequence shows only a low content of small river channel bodies in the northern part of the Rišňovce depression, indicating very low sediment supply and a high accommodation rate. The ratio of sandy-gravelly bodies content reaches $50 \%$ in the southwestern part above the submerged Považský Inovec horst, with notable sediment supply comparing to the accommodation rate. We concluded that FDS of the Pieštany Member was confined by the horst in its northern part and crossed the southern part of the horst from the Blatné depression towards the Rišňovce depression. The change in palaeotransport direction was caused by a more than four times higher accommodation rate. The proportion of sandy channel bodies decreases towards the southern Rišňovce depression to $30 \%$ within an alluvial sequence reaching a thickness of up to $550 \mathrm{~m}$. This shows a high accommodation rate, which exceeded the moderate sediment supply. Comparable conditions are characteristic of the whole Danube Basin with the upper Miocene alluvial sequence, represented by overbank deposits in its main part, being $>1500 \mathrm{~m}$ thick.

The deposition in FDS was preceded by a base level fall associated with incision of the river channels. Then, two linear NW-SE elongated depressions were formed in the northern Blatné depression, emphasizing the direction of palaeotransport across the recently uplifted southern Považský Inovec Mountains. No significant fault activity disrupted the alluvial sequence studied in the Blatné depression. However, the noticeable difference in accommodation rate between the two depressions implies normal fault vertical displacements of up to $400 \mathrm{~m}$ on the Ripňany Fault system, i.e. on the SE margin of the Považský Inovec Mountains. A facies inventory indicates a perennial river environment existing in a humid climate for the period 9.0-6.0 Ma, which is not consistent with published palaeoclimate data. Our observations point to the possibility of a high spatial variability of local climate in the region during the early Messinian.

Acknowledgements. The work was financially supported by the Slovak Research and Development Agency under contracts No. APVV-0099-11, APVV-0625-11, APVV-0315-12, APVV-14-0118, APVV-15-0575 and SK-FR-2015-0017, as well as by the VEGA agency under contract No. 1/0602/16 and by the Comenius University student grant agency under the contract UK/451/2015. This research was initiated and supported by EQUIS, Itd. The authors wish to express their gratitude to the Jadrová energetická spoločnost' Slovenska, a.s., for support of the research. Nafta, a.s. is thanked for providing access to lithological logs of counter-flush boreholes. Many thanks for assistance with the analytical part of the work go to F. Šipka. K. Fordinál and A. Nagy provided valuable remarks regarding the stratigraphy of the area studied. A. Wysocka and an anonymous reviewer are acknowledged for their detailed comments and suggestions, which greatly improved the manuscript.

\section{REFERENCES}

Agustí, J., Cabrera, L., Garcés, M., Krijgsman, W., Oms, O., Parés, J.M., 2001. A calibrated mammal scale for the Neogene of Western Europe. State of the art. Earth-Science Reviews, 52: 247-260.

Allen, J.R.L. 1968. Current Ripples. North Holland Publishing Co., Amsterdam.

Amorosi, A., Pavesi, M., Ricci Lucchi, M., Sarti, G., Piccin, A., 2008. Climatic signature of cyclic fluvial architecture from the Quaternary of the central Po Plain, Italy. Sedimentary Geology, 209: 58-68.

Amorosi, A., Bracone, V., Campo, B., D’Amico, C., Rossi, V., Rosskopf, C.M., 2016. A late Quaternary multiple paleovalley system from the Adriatic coastal plain (Biferno River, Southern Italy). Geomorphology, 254: 146-159.

Anders, I., Stagl, J., Auer, I., Pavlik, D., 2014. Climate Change in Central and Eastern Europe. In: Managing Protected Areas in
Central and Eastern Europe Under Climate Change (eds. S. Rannow, M. Neubert): 17-30. Springer Netherlands, Dordrecht.

Baráth, I., Fordinál, K., Pipík, R., 1999. Lacustrine to alluvial sedimentary cyclicity (Pannonian zone E, Danube Basin). Geologica Carpathica, Special Issue, 50: 14-16.

Beinhauerová, M., Paulík, J., Holzbauer, K., 1969. Správa o reflexno-seizmickom prieskume Podunajskej nižiny $\mathrm{v}$ roku 1968, oblast' piešt’anského výbežku; česky (in Czech). Ústav užité geofyziky, Brno. Manuscript, Geofond Nr. 21265.

Biela, A., 1978. Hlboké vrty $\vee$ zakrytých oblastiach vnútorných Západných Karpát. 1, Záhorská nížina, Podunajská nížina. Regionalna Geología Zapadných Karpát, 10 (in Slovak). Geologický Ústav Dionýza Štúra (Slovak State Geological Survey), Bratislava.

Bielik, M., Kováč, M., Kucera, I., Michalik, P., Šujan, M., Hók, J., 2002. Neo-Alpine linear density boundaries (faults) detected by gravimetry. Geologica Carpathica, 53: 235-244. 
Blair, T.C., McPherson, J.G., 1994. Alluvial fans and their natura distinction from rivers based on morphology, hydraulic processes, sedimentary processes, and facies assemblages. Journal of Sedimentary Research, A 64: 450-489.

Blair, T.C., McPherson, J.G., 2009. Processes and forms of alluvial fans. In: Geomorphology of Desert Environments (eds. A.J. Parsons and A.D. Abrahams): 413-467. Springer, Berlin.

Böhme, M., Ilg, A., Winklhofer, M., 2008. Late Miocene "washhouse" climate in Europe. Earth and Planetary Science Letters, 275: 393-401.

Böhme, M., Winklhofer, M., Ilg, A., 2011. Miocene precipitation in Europe: temporal trends and spatial gradients. Palaeogeography, Palaeoclimatology, Palaeoecology, 304: 212-218.

Boothroyd, J.C., Nummedal, D., 1978. Proglacial braided outwash: a model for humid alluvial fan deposits. Canadian Society of Petroleum Geologists Memoir, 5: 641-668.

Bourlès, D., Raisbeck, G.M., Yiou, F., 1989. ${ }^{10} \mathrm{Be}$ and ${ }^{9} \mathrm{Be}$ in marine sediments and their potential for dating. Geochimica et Cosmochimica Acta, 53: 443-452.

Brestenská, E., Buday, T., Ivan, L'., Seneš, J., 1961. Sekcia C Neogén (in Czech). In: XII sjazd Čs. spoločnosti pre mineralógiu a geológiu, Slovenský výbor, 87-111. Slovak Geological Survey of Dionýz Štúr, Bratislava.

Bridge, J.S., Diemer, J.A., 1983. Quantitative interpretation of an evolving ancient river system. Sedimentology, 30: 599-623.

Bridge, J.S., Lunt, I.A. 2006. Depositional models of braided rivers Braided Rivers, Processes, Deposits, Ecology and Management, International Association of Sedimentologists Special Publication, 36: 11-50.

Bridge, J.S., Tye, R.S., 2000. Interpreting the dimensions of ancient fluvial channel bars, channels, and channel belts from wireline-logs and cores. AAPG Bulletin, 84: 1205-1228.

Bruch, A.A., Utescher, T., Mosbrugger, V., Gabrielyan, I., Ivanov, D.A., 2006. Late Miocene climate in the circum-Alpine realm - a quantitative analysis of terrestrial palaeofloras. Palaeogeography, Palaeoclimatology, Palaeoecology, 238: 270-280.

Bruch, A.A., Uhl, D., Mosbrugger, V., 2007. Miocene climate in Europe - Patterns and evolution: A first synthesis of NECLIME. Palaeogeography, Palaeoclimatology, Palaeoecology, 253: 1-7.

Brügel, A., 1998. Provenances of alluvial conglomerates from the eastalpine foreland: Oligo-/Miocene denudation history and drainage evolution of the Eastern Alps. Tübinger Geowissenschaftliche Arbeiten A, 40: 1-168.

Campo, B., Amorosi, A., Bruno, L., 2016. Contrasting alluvial architecture of Late Pleistocene and Holocene deposits along a $120-\mathrm{km}$ transect from the central Po Plain (northern Italy). Sedimentary Geology, 341: 265-275.

Catuneanu, O., 2006. Principles of Sequence Stratigraphy. Elsevier, Amsterdam

Cohen, K.M., Finney, S.C., Gibbard, P.L., Fan, J.X., 2013. The ICS international chronostratigraphic chart. Episodes, 36: 199-204.

Csillag, G., Sztanó, O., Magyar, I., Hámori, Z., 2010. Stratigraphy of the Kálla Gravel in Tapolca Basin based on multi-electrode probing and well data. Foldtani Kozlony, 140: 183-196.

Čermák, D., 1969. Plytký a stredne hlboký štruktúrny prieskum v Piešt'anskom výbežku, surovina: prieskum živíc, výročná správa za rok 1968 (in Slovak). Slovenské naftové závody, Gbely. Manuscript, Geofond Nr. 22811.

Čtyroký, P., 1959. Zpracování fauny pannonu z Koplotovcú a vrtby UKB P-11 Moravany v Považí. Ústřední ústav geologícký, Praha. Manuscript, Geofond Nr. 6404

Danišík, M., Dunkl, I., Putiš, M., Frisch, W., Král', J., 2004. Tertiary burial and exhumation history of basement highs along the NW margin of the Pannonian Basin - an apatite fission track study. Australian Journal of Earth Sciences, 95-96: 60-70.

Daxner-Höck, G., Harzhauser, M., Göhlich, U.B., 2016. Fossil record and dynamics of Late Miocene small mammal faunas of the Vienna Basin and adjacent basins, Austria. Comptes Rendus Palevol, 15: 855-862.
Erdei, B., Hably, L., Kazmer, M., Utescher, T., Bruch, A.A., 2007. Neogene flora and vegetation development of the Pannonian domain in relation to palaeoclimate and palaeogeography. Palaeogeography, Palaeoclimatology, Palaeoecology, 253: 115-140.

Evans, J.E., 1991. Facies relationships, alluvial architecture, and paleohydrology of a Paleogene, humid-tropical alluvial-fan system: Chumstick Formation, Washington State, USA. Journal of Sedimentary Petrology, 61: 732-755.

Fazli Khani, H., Back, S., 2015. The influence of differential sedimentary loading and compaction on the development of a deltaic rollover. Marine and Petroleum Geology, 59: 136-149.

Fodor, L., Csontos, L., Bada, G., Gyorfi, I., Benkovics, L., 1999. Tertiary tectonic evolution of the Pannonian Basin system and neighbouring orogens: a new synthesis of palaeostress data. Mediterranean Basins: Tertiary Extension within the Alpine Orogen, 156: 295-334.

Fordinál, K., Nagy, A., 1997. Hlavina member - marginal Upper Pannonian sediments of the Rišňovce depression. Mineralia Slovaca, 29: 401-406.

Frisch, W., Kuhlemann, J., Dunkl, I., Brügel, A., 1998. Palinspastic reconstruction and topographic evolution of the Eastern Alps during late Tertiary tectonic extrusion. Tectonophysics, 297: 1-15.

Garga, V.K., Madureira, C.J., 1985. Compaction characteristics of river terrace gravel. Journal of Geotechnical Engineering, 111: 987-1007

Ghazi, S., Mountney, N.P., 2009. Facies and architectural element analysis of a meandering fluvial succession: The Permian Warchha Sandstone, Salt Range, Pakistan. Sedimentary Geology, 221: 99-126.

Gibling, M.R., 2006. Width and thickness of fluvial channel bodies and valley fills in the geological record: A literature compilation and classification. Journal of Sedimentary Research, 76: 731-770.

Gvirtzman, Z., 2001. Lateral thickening of sedimentary units: Sediment compaction vs. tectonics. Tectonophysics, 340: 109-115.

Harvey, A.M., Mather, A.E., Stokes, M., 2005. Alluvial fans: geomorphology, sedimentology, dynamics - introduction. A review of alluvial-fan research. Geological Society Special Publications, 251: 1-7.

Harzhauser, M., Kern, A., Soliman, A., Minati, K., Piller, W.E., Danielopol, D.L., Zuschin, M., 2008. Centennial- to decadal scale environmental shifts in and around Lake Pannon (Vienna Basin) related to a major Late Miocene lake level rise. Palaeogeography, Palaeoclimatology, Palaeoecology, 270: 102-115.

Heller, P.L., Paola, C., 1996. Downstream changes in alluvial architecture: An exploration of controls on channel-stacking patterns. Journal of Sedimentary Research, 66: 297-306.

Hickson, T.A., Sheets, B.A., Paola, C., Kelberer, M., 2005. Experimental test of tectonic controls on three-dimensional alluvial facies architecture. Journal of Sedimentary Research, 75: 710-722.

Horusitzky, H., 1911. Agrogeologische Notiezen aus der Umgebung von Galgóc. Jahresbericht des Königlich Ungarische Geologische Anstalt für 1909. Manuscript, Budapest.

Horvath, F., 1993. Towards a mechanical model for the formation of the Pannonian Basin. Tectonophysics, 226: 333-357.

Horvath, F., Bada, G., Szafian, P., Tari, G., Adam, A., Cloetingh, S., 2006. Formation and deformation of the Pannonian Basin: constraints from observational data. European Lithosphere Dynamics, 32: 191-206.

Hromec, J., 1961. Správa o štruktúrnom prieskume oblasti Bohdanovce-Špačince za rok 1959-1960 (in Slovak) Československé naftové doly, Malacky. Manuscript, Geofond Nr. 8358

Juhász, G., Müller, P., Tóth-Makk, A., 2004. Alluvial architecture and fluvial cycles in quaternary deposits in a continental interior Basin, E Hungary. Geologia Croatica, 57: 171-190. 
Kern, A.K., Harzhauser, M., Soliman, A., Piller, W.E., Gross, M., 2012. Precipitation driven decadal scale decline and recovery of wetlands of Lake Pannon during the Tortonian. Palaeogeography, Palaeoclimatology, Palaeoecology, 317-318: 1-12.

Kern, A.K., Harzhauser, M., Soliman, A., Piller, W.E., Mandic, O., 2013. High-resolution analysis of upper Miocene lake deposits: Evidence for the influence of Gleissberg-band solar forcing Palaeogeography, Palaeoclimatology, Palaeoecology, $\mathbf{3 7 0}$ 167-183.

Kiss, T., Sümeghy, B., Sipos, G., 2014. Late Quaternary paleodrainage reconstruction of the Maros River alluvial fan. Geomorphology, 204: 49-60.

Kooi, H., 2000. Land subsidence due to compaction in the coastal area of The Netherlands: the role of lateral fluid flow and constraints from well-log data. Global and Planetary Change, 27: 207-222.

Kostic, B., Aigner, T. 2007. Sedimentary architecture and 3D ground-penetrating radar analysis of gravelly meandering river deposits (Neckar Valley, SW Germany). Sedimentology, 54 789-808.

Kovács, J., Szabó, P., Kocsis, L., Vennemann, T., Sabol, M., Gasparik, M., Virág, A., 2015. Pliocene and Early Pleistocene paleoenvironmental conditions in the Pannonian Basin (Hungary, Slovakia): stable isotope analyses of fossil proboscidean and perissodactyl teeth. Palaeogeography, Palaeoclimatology, Palaeoecology, 440: 455-466.

Kováč, M., 2000. Geodynamický, paleogeografický a štruktúrny vývoj Karpatsko-Panónskeho regiónu v miocéne: nový pohlad na neogénne panvy Slovenska (in Slovak). Veda, Slovac Academy of Sciences, Bratislava.

Kováč, M., Král, J., Márton, E., Plašienka, D., Uher, P., 1994. Alpine uplift history of the central western Carpathians: geochronological, paleomagnetic, sedimentary and structural data. Geologica Carpathica, 45: 83-96.

Kováč, M., Baráth, I., Halouzka, R., Joniak, P., Sliva, L., Vojtko, R., 2001. Neotektonický vývoj hrastu Považského Inovca a Blatnianskej priehlbiny Dunajskej panvy (in Slovak). Manuscript. Department of Geology and Paleontology, Comenius University in Bratislava.

Kováč, M., Baráth, I., Fordinál, K., Grigorovich, A.S., Halásová, E., Hudáčková, N., Joniak, P., Sabol, M., Slamková, M., Sliva, L., Vojtko, R., 2006. Late Miocene to Early Pliocene sedimentary environments and climatic changes in the Alpine-Carpathian-Pannonian junction area: a case study from the Danube Basin northern margin (Slovakia). Palaeogeography, Palaeoclimatology, Palaeoecology, 238: 32-52.

Kováč, M., Synak, R., Fordinál, K., Joniak, P., 2010. Dominant events in the northern Danube Basin palaeogeography - a too for specification of the Upper Miocene and Pliocene stratigraphy (in Slovak with English summary). Acta Geologica Slovaca, 2 23-36.

Kováč, M., Synak, R., Fordinál, K., Joniak, P., Tóth, C., Vojtko R., Nagy, A., Baráth, I., Maglay, J., Minár, J., 2011. Late Miocene and Pliocene history of the Danube Basin: Inferred from development of depositional systems and timing of sedimentary facies changes. Geologica Carpathica, 62: 519-534.

Kovar-Eder, J., Wojcicki, J.J., 2001. A Late Miocene (Pannonian) flora from Hinterschlagen, Hausruck lignite area, Upper Austria. Acta Palaeobotanica, 41: 221-251.

Králiková, S., Vojtko, R., Hók, J., Fügenschuh, B., Kováč, M., 2016. Low-temperature constraints on the Alpine thermal evolution of the Western Carpathian basement rock complexes. Journal of Structural Geology, 91: 144-160.

Kuhlemann, J., Dunkl, I., Brügel, A., Spiegel, C., Frisch, W., 2006. From source terrains of the Eastern Alps to the Molasse Basin: Detrital record of non-steady-state exhumation. Tectonophysics, 413: 301-316.

Lankreijer, A., Kováč, M., Cloetingh, S., Pitoňák, P., Hlôška, M., Biermann, C., 1995. Quantitative subsidence analysis and forward modelling of the Vienna and Danube basins: thin-skinned versus thick-skinned extension. Tectonophysics, 252: 433-451.
Lankreijer, A., Bielik, M., Cloetingh, S., Majcin, D., 1999. Rheology predictions across the western Carpathians, Bohemian massif, and the Pannonian basin: implications for tectonic scenarios. Tectonics, 18: 1139-1153.

Lebatard, A.E., Bourlès, D.L., Duringer, P., Jolivet, M., Braucher R., Carcaillet, J., Schuster, M., Arnaud, N., Monié, P., Lihoreau, F., Likius, A., Mackaye, H.T., Vignaud, P., Brunet, M., 2008. Cosmogenic nuclide dating of Sahelanthropus tchadensis and Australopithecus bahrelghazali: Mio-Pliocene hominids from Chad. Proceedings of the National Academy of Sciences of the United States of America, 105: 3226-3231.

Leclair, S.F., Bridge, J.S., 2001. Quantitative interpretation of sedimentary structures formed by river dunes. Journal of Sedimentary Research, 71: 713-716.

López, J.L., Steel, R.J., 2015. Laramide signals and architecture of a widespread fluvial sand sheet: Canyon Creek Member, southern Wyoming, U.S.A. Journal of Sedimentary Research, 85: $1102-1122$.

Lunga, S., 1963. Správa o štruktúrnom prieskume v piešt’anskom zálive za rok 1962 (in Czech). Československé naftové doly, Gbely. Manuscript, Geofond Nr. 11330.

Lunga, S., 1964a. Geologická správa o štruktúrnom prieskume geofyzikálnej elevácie Bučany-juh (in Czech). Československé naftové doly, Gbely. Manuscript, Geofond Nr. 12639.

Lunga, S., 1964b. Geologická správa o štruktúrnom prieskume v piešt’anskom zálive za rok 1963 (in Czech). Československé naftové doly, Gbely. Manuscript, Geofond Nr. 12553.

Lunga, S., 1965. Geologická správa o štruktúrnom prieksume v oblasti Bučan za rok 1964 (in Czech). Československé naftové doly, Gbely. Manuscript, Geofond Nr. 14878.

Lunga, S., 1966. Geologická správa o štruktúrnom prieskume v oblasti Bučany - sever za rok 1965 (in Czech). Československé naftové doly, Gbely. Manuscript, Geofond Nr. 16969.

Lunga, S., 1968. Plytký a stredne hlboký štruktúrny prieskum v Piešt’anskom výbežku - prieskum živíc, výročná správa za rok 1967 (in Czech). Československé naftové doly, Hodonín; Prieskumno-t’ažobný závod, Gbely. Manuscript, Geofond Nr. 19833.

MacCarthy, I.A.J., 1990. Alluvial sedimentation patterns in the Munster Basin, Ireland. Sedimentology, 37: 685-712.

Maglay, J., Pristaš, J., Nagy, A., Fordinál, K., Havrila, M., Buček, S., Elečko, M., Kováčik, M., Hók, J., Baráth, I., 2006. Geologická mapa Podunajskej nížiny - Trnavskej pahorkatiny 1:50 000 (in Slovak with English explanations). State Geological Survey of Dionýz Štúr, Bratislava.

Maglay, J., Pristaš, J., Nagy, A., Fordinál, K., Elečko, M., Buček, S., Havrila, M., Kováčik, M., Hók, J., Baráth, I., Kubeš, P., Kucharič, L'., Malík, P., Zuberec, J., Klukanová, A., Liščák, P., Ondrášik, M., Baláž, P., Čurlík, J., Šefčík, P., 2011. Vysvetlivky ku geologickej mape Podunajskej níziny - Trnavskej pahorkatiny 1:50 000 (in Slovak). State Geological Survey of Dionýz Štúr, Bratislava.

Magyar, I., Geary, D.H., Müller, P., 1999. Paleogeographic evolution of the Late Miocene Lake Pannon in Central Europe. Palaeogeography, Palaeoclimatology, Palaeoecology, 147: 151-167.

Magyar, I., Lantos, M., Ujszaszi, K., Kordos, L., 2007. Magnetostratigraphic, seismic and biostratigraphic correlations of the Upper Miocene sediments in the northwestern Pannonian Basin System. Geologica Carpathica, 58: 277-290.

Magyar, I., Radivojevic, D., Sztano, O., Synak, R., Ujszaszi, K., Pocsik, M., 2013. Progradation of the paleo-Danube shelf margin across the Pannonian Basin during the Late Miocene and Early Pliocene. Global and Planetary Change, 103: 168-173.

Marko, F., Plasienka, D., Fodor, L., 1995. Meso-Cenozoic tectonic stress fields within the Alpine-Carpathian transition zone: a review. Geologica Carpathica, 46: 19-27.

Martinsen, O.J., Ryseth, A., Helland-Hansen, W., Flesche, H., Torkildsen, G., Idil, S., 1999. Stratigraphic base level and fluvial architecture: Ericson Sandstone (Campanian), Rock 
Springs Uplift, SW Wyoming, USA. Sedimentology, 46 235-259.

Mattick, R.E., Teleki, P.G., Phillips, R.L., Clayton, J.L., Dávid, G. Poǵcsás, G., Bardócz, B., Simon, E., 1996. Structure, stratigraphy, and petroleum geology of the Little Plain basin, northwestern Hungary. AAPG Bulletin, 80: 1780-1800.

McCarthy, P.J., Martini, I.P., Leckie, D.A., 1998. Use of micromorphology for palaeoenvironmental interpretation of complex alluvial palaeosols: an example from the Mill Creek Formation (Albian), southwestern Alberta, Canada. Palaeogeography, Palaeoclimatology, Palaeoecology, 143: 87-110.

McLaurin, B.T., Steel, R.J., 2007. Architecture and origin of an amalgamated fluvial sheet sand, lower Castlegate Formation, Book Cliffs, Utah. Sedimentary Geology, 197: 291-311.

Melo, M., Lapin, M., Damoborská, I., 2007. Detection of climatic trends and variability at Hurbanovo. In: Bioclimatology and Natural Hazards, International Scientific Conference (eds. K. Střelcová, J. Škvarenina and M. Blaženec), Pol'ana nad Detvou, Slovakia.

Melo, M., Lapin, M., Kapolková, H., Pecho, J., Kružicová, A. 2013. Climate trends in the Slovak part of the Carpathians. In The Carpathians: Integrating Nature and Society Towards Sustainability, Environmental Science and Engineering (ed. J. Kozak): 131-150. Springer, Berlin.

Miall, A.D., 1983. Basin Analysis of Fluvial Sediments. Modern and Ancient Fluvial Systems: 279-286.

Miall, A.D., 2000. Principles of Sedimentary Basin Analysis. Springer, Berlin.

Miall, A.D., 2006. The Geology of Fluvial Deposits: Sedimentary Facies, Basin Analysis, and Petroleum Geology. Springer, Berlin.

Musil, R., 1959. First appearence of the Deinotherium gigantissimum Stefanescu, 1892, in our country. Acta Musei Moraviae, 44: 81-88.

Nádor, A., Sztanó, O., 2011. Lateral and vertical variability of channel belt stacking density as a function of subsidence and sediment supply: field evidence from the intramountaine Körös basin, Hungary. SEPM Special Publication, 99: 375-392.

Niedźwiedź, T., Twardosz, R., Walanus, A., 2009. Long-term variability of precipitation series in east central Europe in relation to circulation patterns. Theoretical and Applied Climatology, 98 337-350.

Nichols, G.J., Fisher, J.A., 2007. Processes, facies and architecture of fluvial distributary system deposits. Sedimentary Geology, 195: 75-90.

Ori, G.G., 1982. Braided to meandering channel patterns in humid-region alluvial fan deposits, River Reno, Po Plain (northern Italy). Sedimentary Geology, 31: 231-248.

Pagáč, l., 1965. Geologické zhodnotenie piešt’anského výbežku a návrh d'alších prieskumných prác (in Czech). Československé naftové doly, Hodonín. Manuscript, Geofond Nr. 14552.

Pavelka, L., Adam, Z., Vašek, J., 1963. Správa o reflexno seizmickom prieskume v Podunajskej nížine, oblast' trnavskej priehlbiny v roku 1962, geofyzikálny prieskum, česky (in Czech) Československé naftové doly, Brno. Manuscript, Geofond Nr. 11293.

Pope, R.J.J., Wilkinson, K.N., 2005. Reconciling the roles of climate and tectonics in Late Quaternary fan development on the Spartan piedmont, Greece. Geological Society Special Publications, 251: 133-152.

Prista, G.A., Agostinho, R.J., Cachão, M.A., 2015. Observing the past to better understand the future: A synthesis of the Neogene climate in Europe and its perspectives on present climate change. Open Geosciences, 7: 65-83.

Pristaš, J., Elečko, M., Maglay, J., Fordinál, K., Šimon, L., Gross, P., Polák, M., Havrila, M., Ivanička, J., Határ, J., Vozár, J., Mello, J., Nagy, A., 2000. Geologická mapa Podunajskej nižiny Nitrianskej pahorkatiny 1:50 000 (in Slovak with English explanatios). State Geological Survey of Dionýz Štúr, Bratislava.

Püspöki, Z., Demeter, G., Tóth-Makk, Á., Kozák, M., Dávid, Á., Virág, M., Kovács-Pálffy, P., Kónya, P., Gyuricza, G., Kiss, J., McIntosh, R.W., Forgács, Z., Buday, T., Kovács, Z., Gombos,
T., Kummer, I., 2013. Tectonically controlled Quaternary intracontinental fluvial sequence development in the Nyírség-Pannonian Basin, Hungary. Sedimentary Geology, 283: $34-56$

Retallack, G.J., 2001. Soils of the Past: An Introduction to Paleopedology. Blackwell Science, Oxford.

Rücknagel, J., Götze, P., Hofmann, B., Christen, O., Marschall, K., 2013. The influence of soil gravel content on compaction behaviour and pre-compression stress. Geoderma, 209-210: 226-232.

Rybár, S., Halásová, E., Hudáčková, N., Kováč, M., Kováčová, M., Šarinová, K., Šujan, M., 2015. Biostratigraphy, sedimentology and paleoenvironments of the northern Danube Basin: Ratkovce 1 well case study. Geologica Carpathica, 66: $51-67$

Rybár, S., Kováč, M., Šarinová, K., Halásová, E., Hudáčková, N., Šujan, M., Kováčová, M., Ruman, A., Klučiar, T., 2016. Neogene changes in paleogeography, paleoenvironment and the provenance of sediment in the Northern Danube Basin. Bulletin of Geosciences, 91: 367-398.

Sliva, L., Vojtko, R., Joniak, P., Kováč, M., Baráth, I., 2002. Sedimentology and tectonics of the Plio-Quaternary sedimentary sequences of southern part of the Považský Inovec Mts. Geologica Carpathica, 53 (Special Issue): 38-40.

Sliva, L.., Fordinál, K., Nagy, A., 2007. Lithofacial analysis and biostratigraphy of the Pieštany Beds (Blatné depression, Slovakia). Scripta Facultatis Scientiarum Naturalium Universitatis Masarykianae Brunensis, Geology, 36: 21-24.

Stanistreet, I.G., McCarthy, T.S., 1993. The Okavango Fan and the classification of subaerial fan systems. Sedimentary Geology, 85: 115-133.

Steininger, F.F., 1999. Chronostratigraphy, geochronology and biochronology of the Miocene "European Land Mammal Mega-Zones" (ELMMZ) and the Miocene "Mammal-Zones (MN Zones)". In: The Miocene Land Mammals of Europe (eds. G.E. Rössner and K. Heissig): 9-24. Verlag Dr. Friedrich Pfeil, München.

Straub, K.M., Esposito, C.R., 2013. Influence of water and sediment supply on the stratigraphic record of alluvial fans and deltas: Process controls on stratigraphic completeness. Journal of Geophysical Research: Earth Surface, 118: 625-637.

Straub, K.M., Wang, Y., 2013. Influence of water and sediment supply on the long-term evolution of alluvial fans and deltas: statistical characterization of basin-filling sedimentation patterns. Journal of Geophysical Research: Earth Surface, 118: 1602-1616.

Syabryaj, S., Utescher, T., Molchanoff, S., Bruch, A.A., 2007. Vegetation and palaeoclimate in the Miocene of Ukraine. Palaeogeography, Palaeoclimatology, Palaeoecology, 253: 153-168.

Sztanó, O., Kováč, M., Magyar, I., Šujan, M., Fodor, L., Uhrin, A., Rybár, S., Csillag, G., Tokés, L., 2016. Late Miocene sedimentary record of the Danube/Kisalföld Basin: interregional correlation of depositional systems, stratigraphy and structural evolution. Geologica Carpathica, 67: 525-542.

Šarinová, K., Maglay, J., 2002. Sedimentology and petrography of Lukáčovce Mb. in the Nitrianska Pahorkatina Upland. Slovak Geological Magazine, 8: 3-11.

Šarinová, K., Slemenský, O., 2009. The jarosite cement in the fluvial sand of the Volkovce Fm. in the locality Hlohovec-brickyard (Neogene, Nitrinaska pahorkatina Upland, Slovakia) (in Slovak with English summary). Mineralia Slovaca, 41: 67-72.

Šujan, M., Braucher, R., Kováč, M., Bourlčs, D.L., Rybár, S., Guillou, V., Hudáčková, N., 2016. Application of the authigenic ${ }^{10} \mathrm{Be} /{ }^{9} \mathrm{Be}$ dating method to Late Miocene-Pliocene sequences in the northern Danube Basin (Pannonian Basin System): confirmation of heterochronous evolution of sedimentary environments. Global and Planetary Change, 137: 35-53.

Thomas, R.G., Smith, D.G., Wood, J.M., Visser, J., Anne Calverley-Range, E., Koster, E.H., 1987. Inclined heterolithic 
stratification-terminology, description, interpretation and significance. Sedimentary Geology, 53: 123-179.

Törokövá, I., 1999. Pliocene deposits of Rišňovce Depression Volkovce Formation. Slovak Geological Magazine, 5: 281-285.

Tóth, C., 2010. Paleoecology and diversity of Neogene proboscibeans (Proboscidea, Mammalia) from the Slovak part of the Western Carpathians area depending on climatic changes and biotic interactions. Mineralia Slovaca, 42 439-452.

Uhrin, A., 2011. Salt and water budget calculations for the Late Miocene Lake Pannon. Foldtani Kozlony, 141: 383-392.

Utescher, T., Erdei, B., Hably, L., Mosbrugger, V., 2017. Late Miocene vegetation of the Pannonian Basin. Palaeogeography, Palaeoclimatology, Palaeoecology, 467: 131-148.

Van Dam, J.A., 2006. Geographic and temporal patterns in the late Neogene (12-3 Ma) aridification of Europe: the use of small mammals as paleoprecipitation proxies. Palaeogeography, Palaeoclimatology, Palaeoecology, 238: 190-218.

Vass, D., Began, A., Gross, P., Kahan, Š., Krystek, I., Köhler, E., Lexa, J., Nemčok, J., Růžička, M., Vaškovský, I., 1988.
Regionálne geologické členenie Západných Karpát a severných výbežkov Panónskej panvy na území ČSSR, Mapa 1:500 000 (in Slovak with English explanatios). State Geological Survey of Dionýz Štúr, Bratislav.

Vašek, J., Novák, J., Adam, Z., 1961. Záverečná správa o reflexno-seizmickom prieskume $v$ MDN - oblast' Hlohovec a pokusných prácach $v$ oblasti Mikulov prevedenom v roku 1960 (in Czech). Československé naftové doly, Brno. Manuscript, Geofond Nr. 8273.

Vejrostová, M., Adam, Z., 1964. Správa o komplexním spracování reflexně seizmického měření v západní části Podunajské nižiny (in Czech). Československé naftové doly, Brno. Manuscript, Geofond Nr. 12668.

Wagreich, M., Salcher, B., Koukal, V., 2009. Late Neogene and Quaternary alluvial fans give evidence for tectonic events at the eastern margin of the Eastern Alps. EGU General Assembly, 19-24 April 2009, Vienna: 5092. 